\title{
Female circumcision in Indonesia. Extent, implications and possible interventions to uphold women's health rights
}

\author{
Meiwita P. Budiharsana \\ Population Council \\ Lila Amaliah \\ Budi Utomo
}

Follow this and additional works at: https://knowledgecommons.popcouncil.org/departments_sbsr-rh

Part of the Community-Based Research Commons, Gender and Sexuality Commons, International Public Health Commons, Maternal and Child Health Commons, Obstetrics and Gynecology Commons, and the Women's Health Commons How does access to this work benefit you? Let us know!

\section{Recommended Citation}

Budiharsana, Meiwita P., Lila Amaliah, Budi Utomo, and Erwinia. 2003. "Female circumcision in Indonesia. Extent, implications and possible interventions to uphold women's health rights," research report. Jakarta: Population Council. 


\section{R esearch R eport \\ Female Circumcision in Indonesia}

Extent, Implications and Possible Interventions to Uphold Women's Health Rights

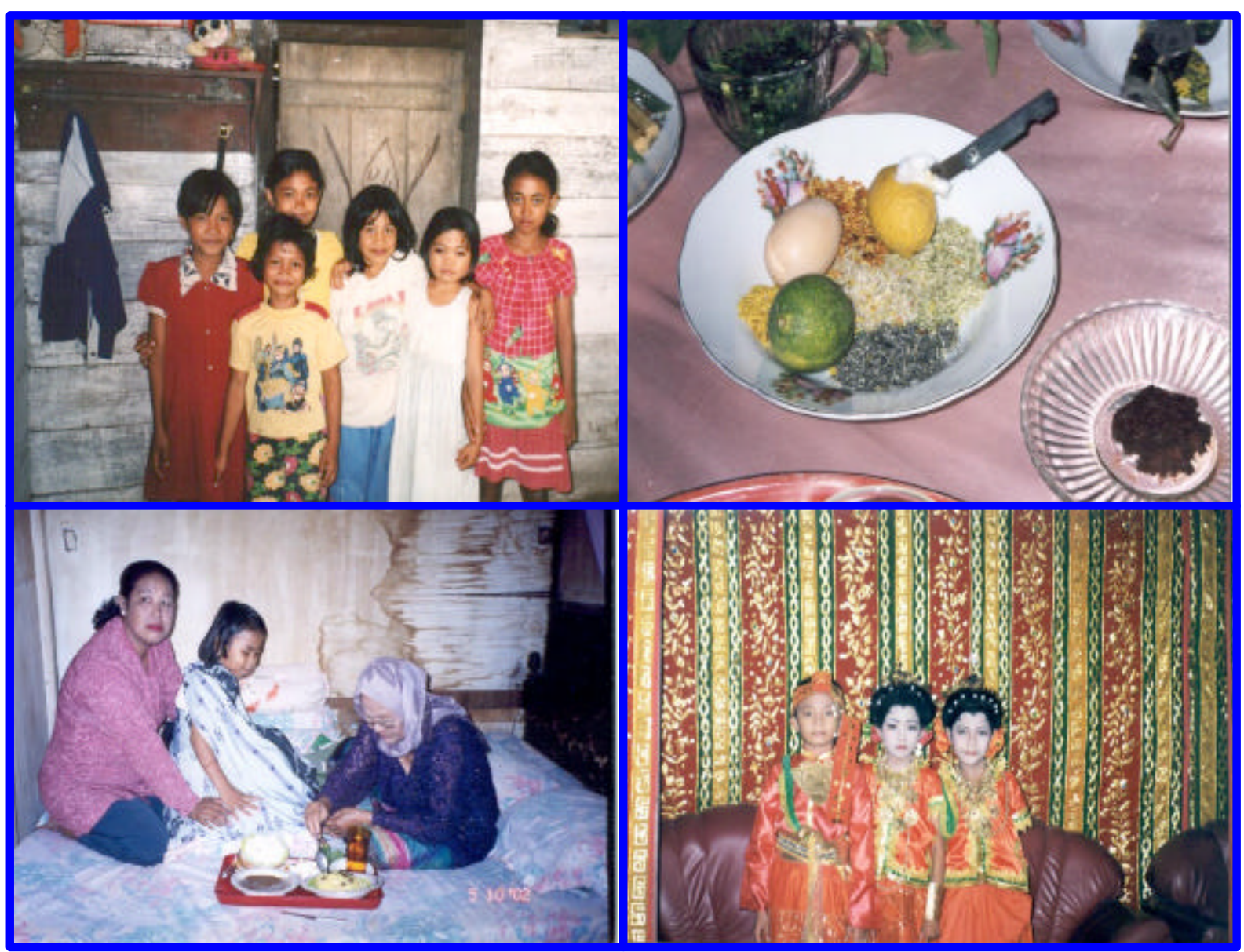

(2) Population Council

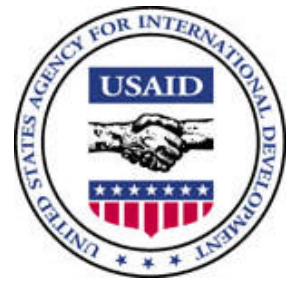




\section{ACKNOWLEDGEMENT}

This study was conducted by the Population Council Jakarta with support from the Ministry for Women's Empowerment under USAID funding. We received considerable support from Ms. Sumali Ray-Ross, a Chief Advisor Program Officer for USAID Jakarta.

Our gratitude goes to Dra. Rieny Hardjono, MPA of the Ministry for Women's Empowerment who have contributed and participated actively in the planning and implementation of this study; and also to Dr. Muhadjir Darwin of the Center for Population and Policy Studies, Gadjah Mada University, Yogyakarta and Dra. Anita Rahman, MHum of the Women Studies Program, University of Indonesia for giving suggestions during research instruments development. We are very grateful to Purwa Kurnia Sucahya, SKM, MSi and Milla Herdayati, SKM for skill transfer and technical suggestions on the quantitative analysis and study field management.

Special acknowledgements go to field coordinators: Jajang Subagja, SKM, Elvyn Bahterawati, SSos, Mansur, SAg, Tasrifin Tahara, SSos, MSc, Andi Aminullah, ST, Meyke Cinthia Rahmola, SKM, Jendrius, S.Sos, MSi and Irwan Samawati, and also to their research team members who had contributed directly to both quantitative and qualitative components of the study. The involvement of dr. Lenggang Kentjana, MARS and dr. Kriel T. Widjajanti, from the Ministry for Women's Empowerment in the second qualitative data collections are greatly appreciated. Our gratitude also goes to Local Bureaus of Women's Empowerment in Padang, Makassar and Gorontalo for their cooperation and contribution during training workshop and data collection. We would like to thank Drs. Mustain Mashud, MSi and Dra. Rahmah Ida, MA of University Airlangga, Drs. Pawennari Hijjang, MA of University of Hasanuddin, and Adief, S.Hut of Yayasan BIKAL for helping the recruitment of competent research assistants.

Special thanks go to Julie Rostina, SKM and Habasiah, SP, MKes who had played significant roles in the overall implementation of this study; Edi Purnama for his thorough data processing and analyses; Febri Syahida, SKM, Yulianingsih, SKM and Budi Ikhwan for their help in data entry. The authors convey their gratitude to Jane H. Patten for her careful translation and editing of the report. Finally, this study would not be completed without full support from Esther Anne Parapak K., SE. Ak and Ms. Indah Pratiwi Siswadi of Population Council Jakarta.

Authors:

Meiwita Budiharsana, Lila Amaliah, Budi Utomo and Erwinia 


\section{Local Research Team Members}

The Population Council - Jakarta Office would like to acknowledge the involvement and great support from each of the local contributors that are listed below:

\section{Qualitative Study I}

$\begin{array}{ll}\text { Banten } & \text { Madura Island } \\ { } } & \text { Jaryono } \\ \text { Titis Aryani } & \text { Lenny Irmawati } \\ \text { Milawati Lusiani } & \text { Marlina Meidiaswati } \\ \text { Sri Kartinah } & \text { Taufiq Rizqon } \\ \text { Farida Sukmawati } & \\ \text { Nani Yunarsih } & \end{array}$

\section{Quantitative Study (Survey)}

Padang
Afriadi
Muharman
Ade Herlina O
Fitrawati
Andriyeni
Djubaedah
Doni Hendrik

\begin{tabular}{l} 
Kutai Kertanegara \\
\hline Mukti Ali \\
Muhammad Khalik \\
Sulastri Septarini \\
Tanti Nur'izzati \\
Agus Sulistiyono
\end{tabular}

\begin{tabular}{l} 
Padang Pariaman \\
\hline Afriadi \\
Delvi Sari \\
Rita Marlifia \\
Rahmat \\
Winda Delfina \\
Wulan Purnama S
\end{tabular}

Serang

Asep Nur Eka

Iim Imaniah

Anisah I. Agustina

Yayah Mubasysyirah

Ira Ambarsari

Sri Kartinah

Farida Sukmawati

Yanti

Shally

\section{Bone}

Nurfaizah

Fadly Husain

Jamila Suyuthi

Siti Hikma Suciati

Handayani

\section{Sumenep}

Ach. Wedianto

Evia Anggraeni

Nina Ari Wahyuni

Hambali Rasidi

M. Imam Haromain

Sri Nurhayati

Makassar
Ashadi
Hartini Nur
Maharani
Hanapiah
Maya S. Djabbar
Muhammad Amin
Muhammad Yunus

\section{Gorontalo}

Karsum Nauko

Rezky Virgana

Melya A. Rahmola

Syaiful. O.Rahmola 


\section{TABLE OF CONTENTS}

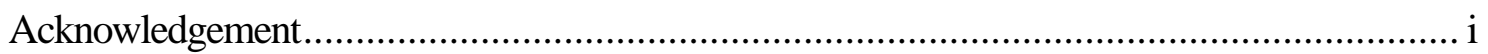

Local Research Team Members ................................................................................. ii

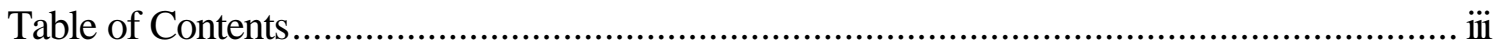

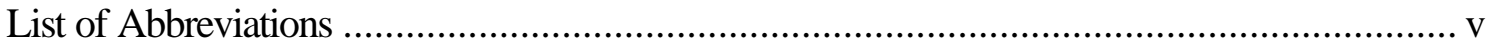

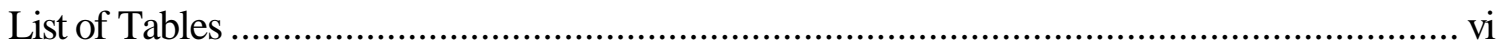

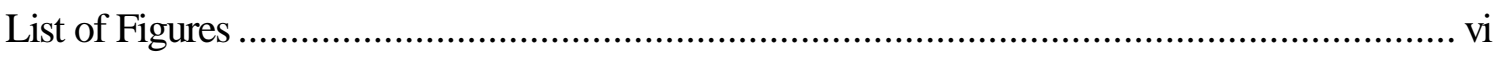

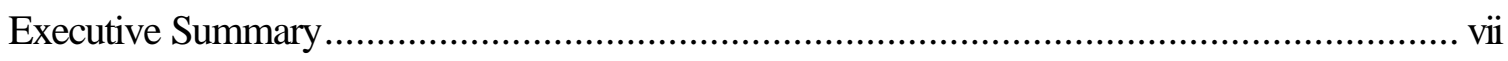

INTRODUCTION



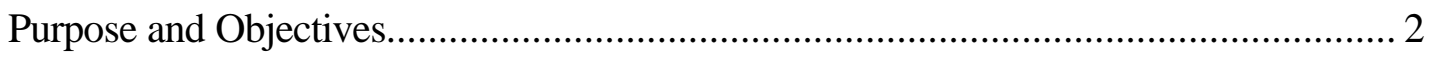

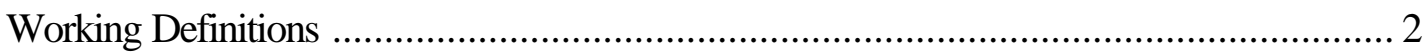

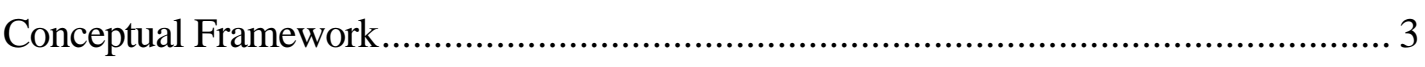

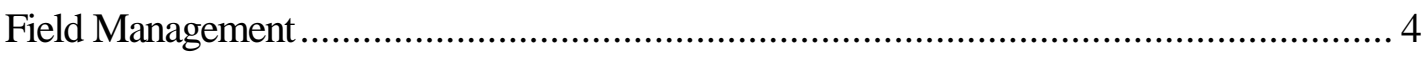

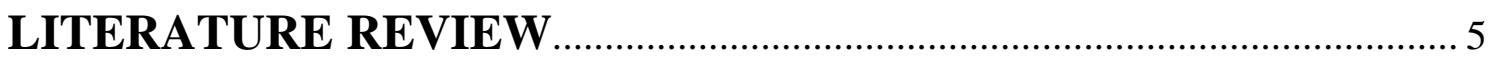

Is Female Circumcision a Violation of Basic Health and Rights Issue? ........................... 5

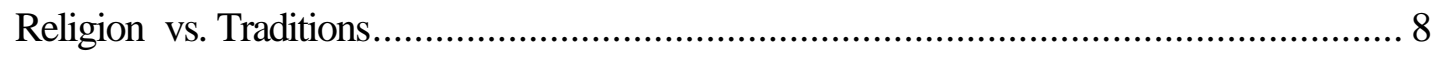

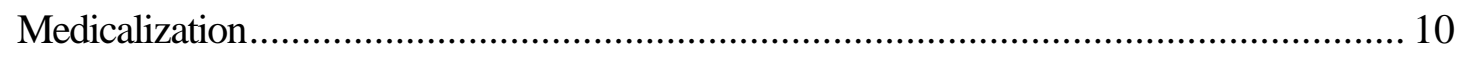



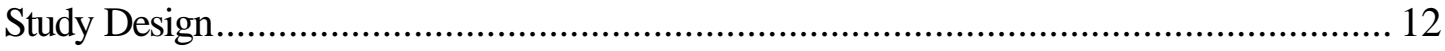

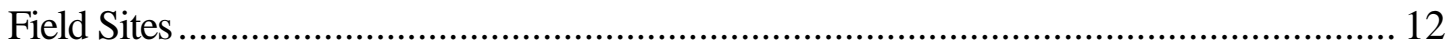

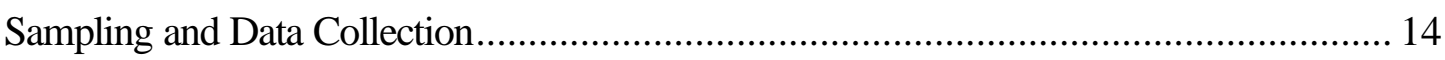

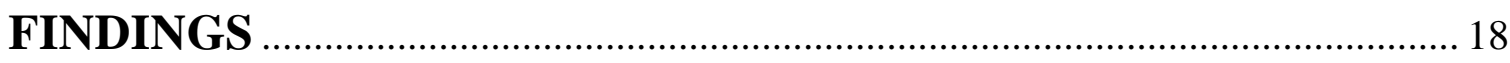

Characteristics of the Sampled Households ................................................................. 18

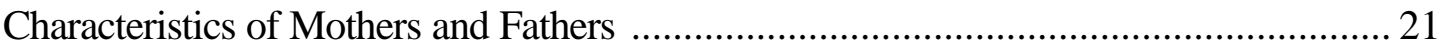




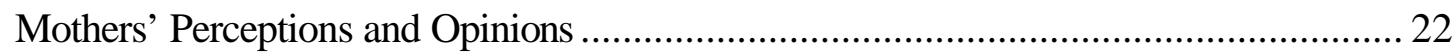

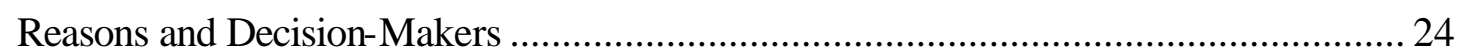

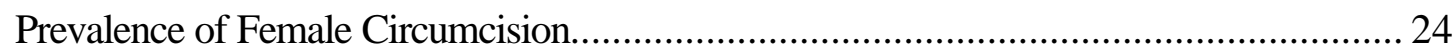

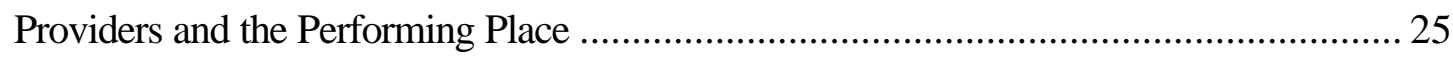

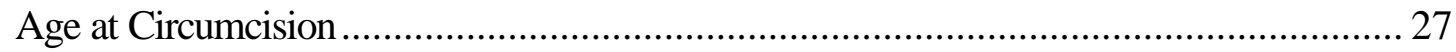

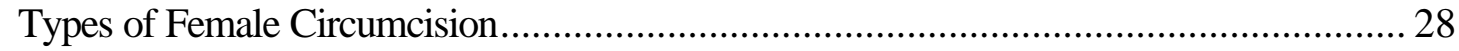

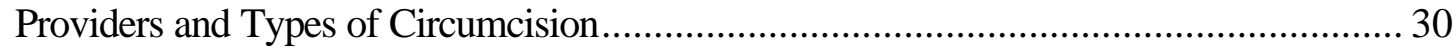

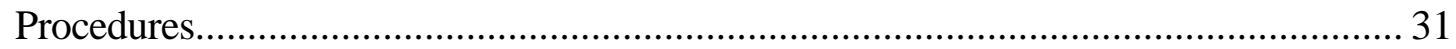

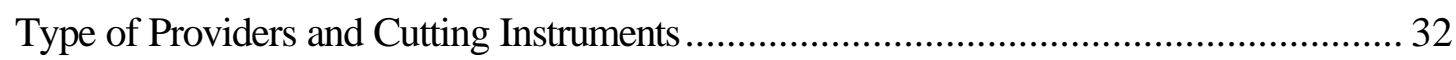



What -and how much - is Cut Off or Removed from the Body? ................................... 34

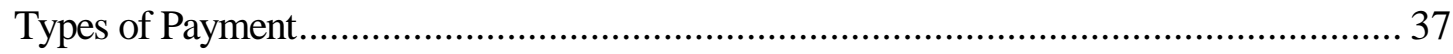

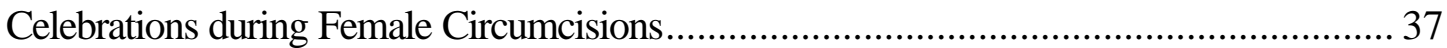

CONCLUSIONS AND RECOMMENDATIONS _...................................... 39

References

Appendices 


\section{LIST OF ABBREVIATIONS}

$\begin{array}{llll}\text { CEDAW } & : & \text { Convention on the Elimination of All Forms of Discrimination } \\ \text { FC } & & \text { Against Women } \\ \text { FGD } & : & \text { Focus Group Discussion } \\ \text { FGM } & : & \text { Female Genital Mutilation } \\ \text { GOI } & : & \text { Government of Indonesia } \\ \text { GP } & : & \text { General Practitioner } \\ \text { HCPs } & : & \text { Health Care Providers } \\ \text { MC } & : & \text { Male circumcision } \\ \text { NGOs } & : & \text { Non-Governmental Organizations } \\ \text { PPS } & : & \text { Probability Proportional to Size } \\ \text { Puskesmas } & : & \text { Pusat Kesehatan Masyarakat (Community Health Center) } \\ \text { MWE } & : & \text { Ministry of Women's Empowerment } \\ \text { TBA } & : & \text { Traditional Birth Attendant } \\ \text { UNFPA } & : & \text { United Nations for Population Fund } \\ \text { UNICEF } & : & \text { United Nations for Children's Fund } \\ \text { US } & : & \text { United States } \\ \text { USAID } & : & \text { United States Agency for International Development } \\ \text { WHA } & : & \text { World Health Assembly } \\ \text { WHO } & : & \text { World Health Organization }\end{array}$




\section{LIST OF TABLES}

Table 1. Number of recruited informants in the first round of qualitative data collection

Table 2. Selected sites for the quantitative data collection

Table 3. Number of informants interviewed in the second qualitative study

Table 4. Household characteristics by sites

Table 5. Monthly expenditure per capita (in thousand Rupiah)

Table 6. Household members' characteristic by sites

Table 7. Education of household members' aged 10 and over by sites

Table 8. Parents' education, and mothers' age and occupation, by sites

Table 9. Mothers' opinions by sites

Table 10. Proportion of girls circumcised by sites (\%) and by age of child at time of survey

Table 11. Proportion of boys circumcised by sites (\%) and by age of child at time of survey

Table 12. Types of provider performing female circumcision by sites

Table 13. Age at female circumcision by sites

Table 14. Proportion of each type of female circumcision performed by sites

Table 15. Percentage of mothers reported bleeding, tissue removal and child crying

Table 16. Use of topical preparation by types of FC

Table 17. Providers and types of female circumcision among eye-witnessed cases, by sites

Table 18. Type of cutting instruments (With-and Without Probing)

Table 19. Types of cutting instruments, by types of FC procedure, among eye-witnessed cases $(\mathrm{N}=1307)$

Table 20. Providers by instrument utilized, among eye-witnessed cases of female circumcision $(\mathrm{N}=1307)$

Table 21. Percentage of mothers who reported actual cutting in FC of their daughters

\section{LIST OF FIGURES}

Figure 1. Conceptual framework used in the analysis of female circumcision and its impact on sexuality and reproductive health status 


\section{EXECUTIVE SUMMARY}

The practice of female circumcision (FC) has recently received increasing attention. The United Nations has declared FC to be a violation of women's rights (1995). Soon after, the United States Congress in 1996 passed legislation directing the U.S. government to oppose assistance to governments of countries where FC or female genital mutilation (FGM) is customarily practiced and where the government has not taken steps to implement educational programs to prevent and eliminate the practice.

In Indonesia, the practice of female circumcision has long existed, but information concerning exactly where and how it is carried out has been limited. In order to gather more information about the procedures in Indonesia, a relatively large study of female circumcision covering several major ethnic groups from the western to the eastern parts of the country, has recently been conducted. The specific aims of the study were to provide research-based information on FC customary practices and their socio-cultural determinants, and if possible, to assess the immediate and long-term physical and psychological consequences of the practices on women's sexuality, reproduction, and reproductive rights. The study used multiple data sources, including literature review, indepth qualitative interviews with FC providers, community leaders, religious leaders, and mothers, and a household survey with a sample of 1694 mothers of female children under age 19. In addition, empirical on-site observations of FC procedures were recorded.

Study findings indicate that in general Muslim communities support the continuation of FC practice, because they perceive it as both a societal custom or tradition, and a religious duty. Religious leaders want the practice of FC to continue indefinitely, because of their common interpretations that $\mathrm{FC}$ is required act of faith, although when being probed, they admitted that the law varies from one mazhab to another, from "wajib" (obligatory) to sunnah (recommended but optional), while some placed it an even lower level of religious duty. Around $92 \%$ of the families visited for the survey expressed support for the continuation of FC not only for their girl children but also for future grandchildren.

On the other hand, twenty years ago, in August 1982, the WHO called for attention to the danger of medicalization of FC. WHO issued a formal statement of opposition, 
advising that "under no circumstances should FC be performed by health professionals or in health establishments" (WHO, 1998). However, this has not been disseminated widely. Extensive medicalization of FC has started in some parts of the country and is underway in others. Many maternity clinic midwives have begun to market FC as part of a birth delivery package. Specifically, medicalization of FC has been established in Padang (92\% of 349 observed cases) and Padang Pariaman (69\% of 323 observed cases) and there is an increasing tendency towards medicalization in Kutai Kertanegara (21\% of 215 observed cases), Sumenep in Madura island (18\% of 275 observed cases), and Serang (14.5\% out of 344 observed cases). The danger of medicalization of FC, lays in the fact that midwives tend to use scissors instead of penknives and thus this tools used for real cutting of the clitoris (incision and excision), where traditional providers more often use penknives for more symbolic acts of scraping or rubbing, and pricking or piercing the outer part of clitoris. Medical personnel should know that there is no such authorized medical procedure, that there are no standardized steps for the so-called operation. Those midwives/doctors are violating the basic elements of professional ethics and their oath to use their skill and knowledge solely for the protection and maintenance of people's mental and physical health.

FC practices can be divided into two main groups: "symbolic only" types where there is no incision or excision, accounting for about $28 \%$ of all the cases of $\mathrm{FC}$ in the study for which an eye-witness account was available, and "harmful" forms, involving incision (49\%) and excision (22\%).

Parents and religious leaders alike were found to have no significant knowledge on the formal links between FC and Islam. We can conclude that the practice of FC in Indonesia is essentially a tradition which has been passed from one generation to the next with little questioning about its meaning or its basis in Islamic history or law. Many adhere to, and pass down, this tradition simply because elders and grandparents wish to preserve this practice in the younger generations.

The study findings did not reveal any clear immediate or long-term physical or psychological complications of FC for girls or women. However, direct observation of procedures showed that FC practice in Indonesia certainly involves pain and real genital cutting in about three-quarters of cases. This evidence, and the fact that it is done without the consent of the girl and without clear health benefits or religious mandate is enough to 
classify this act as a violation of human rights, specifically children's rights and women's sexual and reproductive rights. The practice of FC in Indonesia can therefore be said to violate the rights of the child as guaranteed under the Convention on the Rights of the Child, which was ratified by Indonesia in 1990.

The common argument that FC, if performed under hygienic and medically controlled conditions and by a trained medical provider, is the lesser of two evils compared to the greater risk of severe complications from unhygienic procedures performed by traditional providers, is also not acceptable. Not only is FC a human choice rather that a biological inevitability or imperative, such as birth is, it is also potentially harmful to an otherwise healthy child. Evidence from this study indicates that midwives providing FC tend to perform more invasive forms of FC such as performing more incision and excision (68-88\% of cases, compared to $43-67 \%$ by traditional providers). It is strongly recommended that key donor agencies join together in putting pressure on the Ministry of Health - as the responsible branch of the government's apparatus - to protect girls and women's sexual and reproductive rights. The State Ministry for Women's Empowerment should express a strong demand to hasten the issuance of health policy aimed at stopping the medicalization of FC, specifying that it must not be offered as part of a birth delivery package in maternity clinics or hospital establishments. The State Ministry for Women's Empowerment, the Ministry of Health and the Ministry of Social Affairs, together with the Indonesian Midwives Association (IBI) and the Indonesian Pediatricians Association (IDAI), can put the findings of this study to immediate use in developing policy as well as primary messages as part of a national campaign to ban the practice of FC in health facilities or at people's homes performed by health providers.

While policy and law enforcement can address the issue from the side of reducing the available supply of medical providers for the practice, mass communication system should be used to reduce the demand for FC from the community, which can facilitate consensus building and collective decision-making in support of abandoning the practice of FC. The fact that FC is not obligatory under Islamic law can be emphasized in a mass media campaign and in midwifery training curricula. 


\section{INTRODUCTION}

\section{Background}

The partial or total removal of the external female genitalia or other injury to the female genital organs, known as female genital mutilation (FGM), whether for cultural or for other non-therapeutic reasons, violates the Convention on the Elimination of All Forms of Discrimination Against Women (CEDAW) and the Convention against Torture and other Cruel, Inhumane or Degrading Treatment or Punishment (the 1994 ICPD's Programme of Action, 4.22) (United Nations, 1995). In line with this Programme of Action, the United States (US) Congress in 1996 passed a legislation directing the U.S. government to oppose assistance to governments of countries practicing FGM or female circumcision (FC) as a cultural custom, and those that have not taken steps to implement educational programs to prevent the practice. The US State Department of Justice through the USAID/Indonesia in early 2001 identified FC as one of priority area of interventions.

On the same line, the Government of Indonesia (GOI) through the National Action Plan for the Elimination of Violence Against Women has stated its commitment to address FC. This national action plan falls under the responsibility of the State Ministry of Women's Empowerment (SMWE), whose function is to help other ministries integrate gender equality perspective, including the budget implication, into their policies and programs.

In Indonesia, the perils of FC are still unknown. Despite widely practiced, information regarding current types of FC, the extent of the practice, or its impact on women's health and sexual life in Indonesia has been limited. The relatively comprehensive review of FC practices in Indonesia is only available during the period of Dutch Colonization. Several recent studies on FC have not yet pictured the extent and variation of FC practices in the Indonesia's ethnically diverse archipelago. To enhance understandings such FC practices and their extent and variation in the country as well as their causes and implications, the USAID/Indonesia commissioned the Population Council to conduct a study to address the following FC related issues: 
- Do the customary practices of FC and their socio-cultural determinants differ between sites?

a Have the customary practices changed over time?

- How far would the customary practices of FC relate to human rights, women's sexuality and reproductive rights, and child rights?

- What are possible interventions to end the harmful practice of FC in order to protect women's sexuality, reproductive health, and reproductive rights?

\section{Purpose and objectives}

The purpose of the study is to provide research-base information regarding FC customary practices and their socio-cultural determinants in Indonesia, as well as possible immediate and long-term physical and psychological consequences of the practices on women's sexuality, reproduction, and reproductive rights. With this information, the National Action Plan for the Elimination of Violence against Women can be carried with confidence. This would accelerate effective public awareness campaigns to end harmful FC practices and gender inequality in sexuality and reproductive rights. Thus, the study has three specific objectives:

To determine the nature, magnitude, and patterns of FC practice and their social determinants in Indonesia;

- To identify physical and psychological effects of FC, its immediate and long term complications, types of treatment, and the skill levels of operators;

a To supply the State Ministry of Women's Empowerment (SMWE), the Ministry of Health (Departemen Kesehatan), and the Ministry of Social Affairs (Departemen Sosial) with information that can be used to develop primary messages for a national campaign to end harmful FC practices.

\section{Working Definitions}

FC refers to the unclassified type or Type IV of the WHO's classification on Female Genital Mutilation (FGM). Both FC and FGM practices involve similar rituals that serve to perpetuate customs that seek to regulate and take control over the body and sexuality of the individual. However, FGM is much more drastic and damaging to women (Sarkis, 1995). The last version of FGM definitions was reaffirmed in the WHO, UNICEF, 
and UNFPA joint-statement issued in April 1997. Based on its severity, there are four major types (WHO, 1998:4):

Type I Excision of the prepuce, with or without incision of part or the entire clitoris

Type II Excision of the clitoris with partial or total excision of the labia minora

Type III Excision of part or all of the external genitalia and stitching/ narrowing of the vaginal opening (infibulation)

Type IV Unclassified, which includes: pricking, piercing or incising of the clitoris and/or labia; stretching of the clitoris and/or labia; cauterization by burning of the clitoris and the surrounding tissue; scraping of tissue surrounding the vaginal orifice ('angurya' cuts) or cutting of the vagina ('gishiri cuts'); introduction of corrosive substances or herbs into the vagina to cause bleeding or for the purposes of tightening or narrowing it; and any other procedure that falls under the definition of FGM given above

\section{Conceptual Framework}

The genesis of FC or FGM is unclear. The cited perceived benefits for practicing FC or FGM include (WHO, 1996a; 2000):

- Psychosexual reasons: perceived beliefs that reduction or elimination of the sensitive tissue of the outer genitalia, particularly the clitoris, can attenuate sexual desire in the female, maintain chastity and virginity before marriage and fidelity during marriage, and increase male sexual pleasure. Male attitudes to sex and sexual pleasure in the communities practicing female circumcision may support this belief. For example, anecdotal reports suggest that in some communities practicing infibulation, achievement of difficult penetration of a tight vagina was a proof of virginity following marriage;

- Sociological reasons: identification with the cultural heritage, initiation of girls into womanhood, social integration, and the maintenance of social cohesion; 
- Hygiene and aesthetic reasons: the external female genitalia are considered dirty and unsightly and are to be removed to promote hygiene and provide aesthetic appeal;

a Myths: enhancement of fertility and promotion of child survival;

- Religious reasons: some Muslim communities practice FGM in the belief that it is demanded by the Islamic faith although this customs, however, predates Islam.

These cited perceived benefits, affect decision-making within the family about the FC practices. The timing decision-making process is also influenced by the socio-culturalenvironmental factors, including socio-economic characteristics, region or ethnic, and peer pressure. Type of circumciser, type of cutting instrument, and type of cutting might associate with the extent of FC impact on women's sexuality, reproductive health, and reproductive rights.

Figure 1. Conceptual framework used in the analysis of female circumcision and its impact on sexuality and reproductive health status

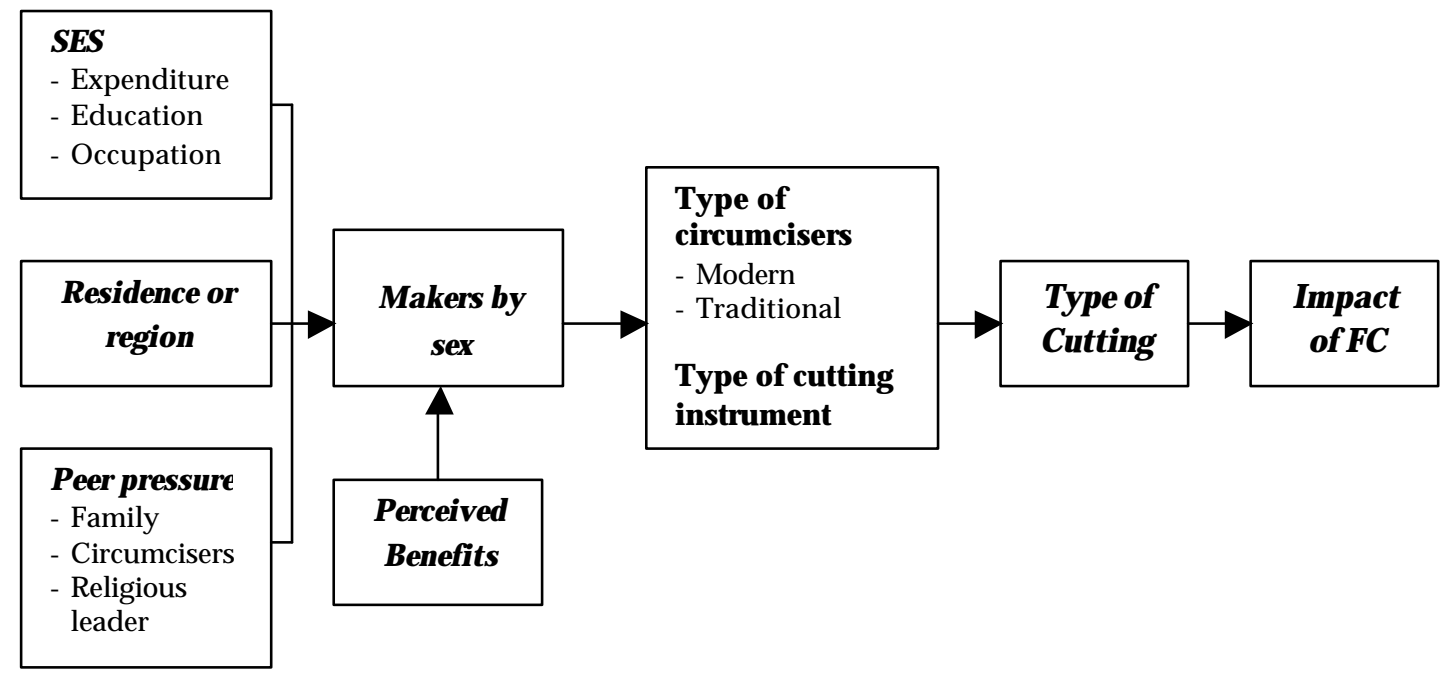

\section{Field Management}

The Population Council managed the overall study with the backup political support from the State Ministry of Women Empowerment. In the field, however, many local personnel and organizations including universities and non-governmental organizations were directly and indirectly involved in the study activities. 


\section{LITERATURE REVIEW}

\section{Is Female Circumcision a Violation of Basic Health and Rights Issue?}

The World Conference on Human Rights in 1993, the International Conference on Population and Development in 1994, and the United Nations Fourth World Conference on Women in 1995 clearly stated that FGM is a violation of reproductive and health rights. Female circumcision is inevitably a form of FGM, and thus the term FGM is more accurate and stronger. The definition of FGM constitutes all procedures from partial to total removal of the external female genitalia or other injury to the female genital organs whether for cultural or any other non-therapeutic reasons (WHO, 1996). This changes in language from FC to FGM was inserted in the Resolution of the $46^{\text {th }}$ World Health Assembly (WHA46.18) as a recognizable shift from addressing the practice merely as a health issue, to accepting it as both a health and a human rights issue (WHO, 1998). The violation of the basic human and health rights of the girl child lies in the fact that this practice is an infringement upon the physical and psychosexual integrity of women and girls, and without a therapeutic reason this is a form of violence against them. Therefore, the Resolution WHA46.18 urged related countries to continue the monitoring and evaluation of their efforts to eliminate any form of FGM, because it is unacceptable from any point of view (WHO, 1997).

Unlike findings of FGM practices in Africa that tends to ruin almost all female genital parts, from the cutting of all the clitoris, labia minora, to even stitching the vagina and only leaving a hole for sexual intercourse, the literature review on FC practices in Indonesia could not present sufficient evidence of a harmful traditional practice with sexual, reproductive and psychological health impacts. This implies that any efforts to eliminate FC can not be carried out by health and development advocates simply using legal and international human rights mechanisms related to the concept of women's equity, health rights and bodily integrating. The most effective strategies must include women's empowerment so that the struggle to stop FC (as a harmful form of FGM) could be led by women from the communities where it occurs (WHO, 1998). Certain consideration should 
be given to traditional FC rituals that in practice merely rubbing and not cutting of the female genitalia.

Literature in Indonesia showed that people use different words for FC practices, which vary from any rubbing, tearing, piercing to actual cutting of the female genitalia (Suswati, 1997; Tatapangarsa, 1980). The most common word for FC is female khitan. Khitan, originally came from an Arabic word 'khatana', means cutting the prepuce of a male genital part. According to a quote in the book of Women's Fiqh, female khitan is cutting part of the skin of labia minora or kelentit (preputium clitoridis) at the top of urethra and farji (vagina's entrance), which usually has the shape of jengger ayam (rooster's comb) or biji kurma (seed of dates). Another word that is commonly mentioned is sunat, in reference to the Prophet PBUH's requisition or sunnah fitrah (www.keluargamuslim.com). Less popular words include: khifad which came from khafd, a specific term for female khitan only, meaning to lower down the voice (while specific term for male only is called I'zar) (http://www.keluargamuslim.com).

The unique situation in Indonesia explained why FC related research in Indonesia could not easily use the WHO classification of type I, II and III (WHO, 1998). As defined, WHO describes: Type I, as the excision of the prepuce, with or without excision of part or the entire clitoris; Type II, as the excision of the clitoris with partial or total excision of the labia minora; and Type III, as the excision of part or all of the external genitalia and stitching/narrowing of the vaginal opening (infibulation). The FC practices in Indonesia seem to relate to the descriptions in the unclassified type (Type IV) which combines: pricking, piercing or incising of the clitoris and/or labia, stretching of the clitoris and/or labia, cauterization by burning of the clitoris and surrounding tissue; scraping of tissue surrounding the vaginal orifice or cutting of the vagina, introduction of corrosive substances or herbs into the vagina to cause bleeding or for the purposes of tightening or narrowing it; and any other procedure that falls under the definition of FGM given above (WHO, 1998).

The existing literature could not present any evidence that FC in Indonesia is similar to FC in Egypt and some African countries. None of the literature in Indonesia described the process of genital cutting as an excision of the prepuce or any part of the clitoris. The three studies conducted in late 1990s reported only opinion and perception of 
religious leaders, parents, and trained midwives. None of them did a direct observation of the process to witness the procedure of circumcision. This made it difficult to prove that existing FC practice is a form of violence against the girl child with a significant life-effect that manifest when entering adulthood (Adrina et al, 1998; Feillard and Marcoes, 1998; Rahman, 1999). Adrina et al (1998) reported that bleeding is a must according to 94 female respondents that they interviewed, but did not do any direct observation. Feilard and Marcoes (1998) concluded that there was very little difference between FC procedures before and after 1945. Before 1945 circumcisers used turmeric and after 1945 they used Betadine to prevent infection. They did describe four terms of circumcision: (1) cutting off the tiny upper part of the clitoris; (2) tearing off the skin with a curved needle; (3) rubbing off the skin or secret around the clitoris without cutting any part of it; and (4) piercing with a needle or the edge of a knife to extract a single drop of blood, but nothing was cut off. However, they did not conduct any direct observation to validate which of the above practices was the most frequent occurred. Marcoes presented a questionable finding whereas she witnessed one FC procedure in Sukabumi in which a tiny clitoral part was cut off, and the child was crying and screaming. However, she did not see any bleeding. Rahman (1999) presented merely opinion of religious leaders about FC without direct observation of FC practice. In sum, there is insufficient report that FC practices are the source of physical, sexual or psychological harm suffering, either manifested in a woman's private sexual life, fertility history, or other effects at the community or public levels. In relation to the recommendation of the World Conference on Human Rights to intensify governments' efforts for the protection and promotion of the human rights of women and the girl child, a direct observation of the FC process needs to be done before concluding that FC in Indonesia is a threat to the human rights of girl children in Indonesia.

Bleeding reported during FC was instantly stopped by wiping it with cotton or gauze. However, this information is insufficient to categorize the practice as described in the WHO FGM Type I, in which the clitoris would be held between the thumb and index finger, pulled out and amputated with one stroke of the sharp object (WHO, 1998). The existing literature of FC practices in Indonesia did not specify the degree of severity of the cutting, whether the clitoris was amputated totally or partially, as in the FGM literature. None also revealed any cases with severe infections or stitches. 
In conclusion, our literature review could not lead to a clear indication that FC practices in Indonesia violate women's and girl-child's human rights. Primary data collection from direct observation of FC processes is needed to present evidence whether:

(A) The types of FC practices in Indonesia cover rubbing, pricking, piercing, or cutting off the clitoris and/or labia.

(B) Any of the following two groups of complications occur (IPPF, 2001):

1. Short term complications, in the forms of:
a. bleeding
b. infection (that can result in fatal septicaemia)
c. tetanus, or
d. gangrene.

2. Long term consequences, such as:
a. persistent pain
b. sexual dysfunction
c. chronic urinary tract infection
d. incontinence, and
e. infertility.

\section{Religion vs. Traditions}

Previous studies in Indonesia confirmed findings from international literature that FC is not a religious requirement for Muslims in Indonesia. FC is merely the practice of tradition. There is no verses in the Qur'an that support FC, however, many associated the practice with the hadith or sayings in which the Prophet Muhammad PBUH instructed the circumciser to "Cut off only the foreskin (the prepuce or outer fold of skin over the clitoris) and do not cut off deeply (not cutting the clitoris itself), for this is brighter for the face (of the girl) and more favorable with husband." This hadith is quoted by many Islamic scholars such as Al-Hakim, Al-Baihaqi, and Abu Dawood.

Most Indonesian Muslim leaders know that, "Circumcision is a commendable act for men (sunnah) and merely an honorable thing for women (makromah)" (Al-Shawkani cited in Badawi, 2002, Salim Al-Awwa, n.d). Sunnah includes the words, actions and approval (or consent) of Prophet Muhammad. In the context of religious obligation, sunnah refers to acts that are commendable but not obligatory. Therefore, the above hadith 
distinguishes male circumcision (MC) as a religious obligatory practice from the nonobligatory of female circumcision (FC) by using the term sunnah. The existing hadiths that refer to the removal of a miniscule segment of skin from the female prepuce clearly emphasize that FC practice should not provide any harm to the girl-child. This is merely a ritual act of tolerance to the pre-Islamic practices (the dark age or jahiliyah). It is clear that removal of partial or complete clitoris (clitoridectomy) or the entire labia minora, and medial part of labia majora (infibulation) were never mandated because these acts will impair a woman's ability to enjoy sexual relations (www.minaret.org/fgm.htm; http://www.jannah.org/genderequity/equityappendix.html). A confirmation of this point of view is found in another part of Islamic law that protects a woman's right to sexual enjoyment, by allowing a woman to divorce her husband who could not provide sexual satisfaction (ibid).

A majority of Muslims in Indonesia are followers of mazhab Syafi' $i$ who perceives circumcision as an obligatory practice for boys and girls, in contrast to followers of mazhab Maliki who perceive male circumcision as an obligatory rule but FC merely as a symbolic gesture. The other two mazhab Hambali and Hanafi believe that circumcision is a sunnah for men and a sign of respect for women (Salam, 1994 quoted in Rahman, 1999; Tatapangarsa, 1980).

Unfortunately, individual interpretation in various places has turned this cultural tradition into a religious doctrine that commands FC as a basic element of religious faith, similar to the abstention of pork in daily food. They declared FC practices as a required act of purification, or a pre-condition to become a Muslim (Ramali, 1951, cited in Feillard and Marcoes, 1998; Adrina et al, 1998; Tatapangarsa, 1980; Research Team of LSPPA, 1999). In Limbangan, Central Java, the Islamic religious leaders perceived that FC is required by the Islamic law (sunnah or recommended by the Prophet), a duty for male believers as well as for the females. However, the researchers found out that in reality circumcision was practiced by non-Islamic Javanese too, a practice inherited as a custom or tradition (Research Team of LSPPA, 1999).

Feillard and Marcoes (1998) concluded that FC practices in Indonesia were introduced by Islamic scholars who introduced Islam, because these practices were presented only in regions where the majority of the population are Muslim and is non- 
existent in the areas where non-Muslim ethnic groups live such as the islands of Nias, Timor, Lombok, Sumba, Flores, Solor, Roti, and among the ethnics of Batak in North Sumatra and Dayaks in Kalimantan.

Post economic crisis of 1998, it was noticed that poverty induced the sharp escalation of Islamic fundamentalism all over the country. In West Java, for instance, a newspaper article (Pikiran Rakyat, June 11, 2001) advertised openly mass FC events organized regularly by the Assalam Foundation who own an Islamic boarding school (pesantren) with thousands of students (santris). They claimed that FC practices up to the age of 10 years had been done as frequently as male circumcision, since 1948,

What made people believed that FC is a pre-condition to become a Muslim is the fact that reputable Islamic leaders like Kyai Ali Yafie, who is known to be gender sensitive, also still emphasized the continuation of FC practices "according to current directives" (Feillard and Marcoes, 1998: 366). Stigmatization is another fear if one is not circumcised. In Madura, circumcision is viewed as a must for Muslims, both males and females, and those who are not circumcised will be stamped as kafir (non-believer) (cited in Darwin et al, 2001).

\section{Medicalization}

The arguments against FGM are based on universally recognized human rights, including rights to the highest attainable level of physical and mental health, therefore, any form of FGM is unacceptable from any health care providers (HCPs) point of view (WHO, 1997). The message is clear that FGM must not be institutionalized, nor should any form of FGM be performed by any health professionals in any setting or health establishments (WHO, August 1996). Medicalization is the involvement of HCPs in performing FGM, although it might emerge from the intention to reduce the health risk of genital cutting performed by traditional birth attendants or traditional circumcisers. The WHO has called for a major effort to prevent the medicalization of all forms of FGM, based on the ethics of health care where body mutilation cannot be condoned by a HCP whether for cultural or any other non-therapeutic reasons (WHO, August 1996). Disappointingly, medicalization is the factor that seems to contribute to the increased practices of FC in Indonesia (Feillard and Marcoes, 1998). 
Between 1996 and 2002, more and more trained HCPs performed FC in Indonesia (Feillard and Marcoes, 1998; Adrina et al, 1998; Rahman, 1999). The Ministry of Health never inform the public about WHO's call for eliminating FC by HCPs. The practice of FC by midwives or nurses at home and in clinics was basically ignored. Unlike data from Egypt, which show that physicians undertake more than half of all female genital cutting cases in Egypt, there is no data on the percentages of FC performed by trained HCPs in Indonesia (Pyle, 2001). The suspicion is that there is an increasing tendency of FC cases in urban areas, performed by medical personnel.

Among those who believe that, "the tradition (FC) should continue to grow and develop in society," medicalization is expected to reduce the risk of health complications and thus FC in clinical settings is promoted as part of a birth delivery package, together with vaccination and ear piercing (tindik) for a baby girl.

Among the supporters of human rights, two came out this year in the popular printed media, where concerned journalists interviewed medical doctors who stated that FC is unnecessary (Ayahbunda, No. 07/2002; Republika, April 21, 2002). The last one added the fact that the consequences of FC include sexual dysfunction that is an integral part of one's quality of life. 


\section{METHODS}

\section{Study Design}

The study used sequential data collection and analysis: (1) a review of related literature to unravel the patterns of FC practices including their gender and socio-cultural determinants; (2) a qualitative study for refining research questions and approaches to be used in the quantitative study; (3) a quantitative study to estimate the prevalence and distribution of the FC practices; (4) a qualitative study to explore sensitive information and to comprehend the research-findings.

\section{Field-sites}

The first qualitative study, conducted before the larger quantitative study, covered Pandeglang and Serang Districts in Banten Province, and Madura Island in East Java Province. The second qualitative study, conducted after the quantitative study, covered Padang Pariaman district in West Sumatra, Gorontalo District in Gorontalo, Makassar City in South Sulawesi, and Bandung City of West Java. The quantitative study covered 8 different sites of six provinces, West Sumatra, Banten, East Kalimantan, East Java, Gorontalo, and South Sulawesi, intended to represent the country's western, central and eastern regions. Below are brief physical and social descriptions of the study sites as to provide the study settings.

Banten Province: Banten, which was previously part of West Java Province, became a new province in 2002. The province is located in the west-northern part of Java bordered by Java Sea and the Jakarta Special Territory on the north, West Java Province on the south and the Sunda Strait on the west. The province is administratively divided into four districts (Serang, Lebak, Pandeglang, and Tangerang) and two cities (Tangerang and Cilegon). Based on the 2000 Census, the total Banten population was 8.10 million consist of 4.08 million males and 4.02 million females. The major ethnic groups in Banten included Bantenese, Sundanese (Priangan), Javanese and Betawi. Muslim is the major religion $(96 \%)$. 
Madura Island: Madura is a long, narrow island at the eastern end of Java's north coast, and is part of the East Java Province. The island stretches 160-kilometer length from east to west and 35 kilometers from north to south, amounting to a total area of roughly 4,250 square kilometers. Madura is divided into four districts: Bangkalan, Sampang, Pamekasan and Sumenep. Beside the main landmass, there are 67 more small islands and islets, 66 of which are part of that Sumenep District, while one island belongs to Sampang. The population of Madura stood at 3.13 million, consisting of 1,50 males and 1,63 females (BPS, 2000). The Madura people speak Madurese.

Padang City and Padang Pariaman: Both sites are located at the West Sumatra Province, which is the home of Minangkabau, one of Indonesia's most interesting and influential ethnic groups. The Minangkabau are versatile and intelligent people who lead a community and family life based on a matrilineal system that gathers around mosques and traditional adat houses. It is the women who own property and the men who choose to wander. Padang City with the total area of 694.96 square kilometers is the capital city of West Sumatra Province. The city is bordered by three districts: Solok, Pesisir Selatan, and Padang Pariaman, and the Indonesian ocean. In regard to the Padang Pariaman District, the total area is 1,329 square kilometers with a total population of 363,706 persons and a population density of 274 per square kilometers.

Gorontalo District: It is the most populated and the largest area in Gorontalo Province. The district is bordered by Sulawesi Sea on the north, Bolaang Mongondow District (North Sulawesi) on the east, Tomini gulf on the south and Boalemo District and South East Sulawesi Province on the west. The total area of Gorontalo district is 5,411,38 square kilometers. The population of Gorontalo district stood at 514,107 persons in 2001.

Kutai Kartanegara - East Kalimantan: The total area of Kutai Kartanegara District or Kutai is 27,263 square kilometers or 46\% of East Kalimantan province and bordered by Berau District and Bulungan District on the north, Makassar strait on the East, Balikpapan City and Pasir District on the south, and Central Kalimantan Province, West Kalimantan Province and Malaysia on the west. The total population of Kutai is 715,495 persons with a population density of 16 per square kilometers (BPS, 2001). Most of the population lives in the villages $(80,6 \%)$. The people in Kutai is divided into the locals including Kutai and Dayak ethnic groups; and the outsiders including Javanese, Banjar, Bugis, Madurese, 
Padang, Toraja, Ambonese, Chinese, and Malay. The majority of religion followers were Muslim especially those who live along the Mahakam River and coastal areas. Other followers includes Christian, Catholic, Hindu dan Budhist. Animist and Dynamist also still exist, among especially people who live in hinterland.

Makassar City and Bone District-South Sulawesi Province: The total area of Makassar city was 176 square kilometers, with the total population of 557,050 males and 573,334 females in 2001. The majority of religion followers are Muslim. Makassar City is the capital city of South Sulawesi Province. The city borders are Pangkep District on the north, Maros District on the east, Gowa District on the south and Makassar Strait on the west. In regard to Bone District, its total area was 4,559 square kilometers with the total population in 2001 of 308,433 males and 346,658 females and a population density of 144 people per square kilometers. The district borders are Sinjai District on the north, Wajo District on the south, Soppeng District, Barru District, Pangkep District, Maros District and Gowa District on the east, and Southeast Sulawesi on the west.

\section{Sampling and Data Collection}

\section{The First Qualitative Study}

Social mapping of FC practices was first conducted through emails, phone-calls and direct interviews of key related persons and organizations, including local universities and non-governmental organizations (NGOs). The mapping was designed as to identify key aspects of FC practices including the geographic locations, ethnic groups, and related providers. The social mapping tracked down potential groups of respondents for the first qualitative study, which included religious and community leaders, traditional birth attendants/healers, health care providers, and other community members, such as the housewives, street vendors, traditional market visitors, and public transport drivers and passengers. Purposive and quota sampling methods were used to recruit respondents from the identified groups. Data on FC related practices were collected through in-depth interviews, which had also produced snowball effects on the recruitment of more informants and the collection of more information not only from the site, but also from other locations. Overall, there were 115 informants consisting of female and male traditional and modern providers, female and male religious leaders, and parents. While 
most of the recruited traditional and modern FC providers were females, most of the recruited religious leaders were males, and all were Muslim leaders.

Table 1. Number of recruited informants in the first round of qualitative data collection

\begin{tabular}{|c|c|c|c|c|}
\hline Category & & $\begin{array}{l}\text { Pandeglang and } \\
\text { Serang }\end{array}$ & Madura & Total \\
\hline \multirow[t]{2}{*}{ Traditional provider } & $\begin{array}{l}\text { Female traditional birth } \\
\text { attendant }\end{array}$ & 12 & 12 & 24 \\
\hline & Male circumciser & 3 & 2 & 5 \\
\hline \multirow[t]{2}{*}{ Modern provider } & Female midwife & 14 & 13 & 27 \\
\hline & Male nurse & 5 & 3 & 8 \\
\hline \multirow{2}{*}{$\begin{array}{l}\text { Religious leader } \\
\text { (Muslim) }\end{array}$} & Female & 2 & 1 & 3 \\
\hline & Male & 12 & 10 & 22 \\
\hline \multirow[t]{2}{*}{ Parent } & Mother & 15 & 7 & 22 \\
\hline & Father & 2 & 2 & 4 \\
\hline Total & & 65 & 50 & 115 \\
\hline
\end{tabular}

\section{The Quantitative Study}

As previously mentioned, the quantitative study was conducted in 6 rural districts and 2 urban cities of six provinces. These 8 sites were purposively selected as to represent the country's western, central, and eastern regions. The inclusion of rural and urban sites was meant to picture, if any, the urban rural differentials of the FC practices.

Table 2. Selected sites for the quantitative data collection

\begin{tabular}{|c|c|c|c|c|c|c|c|c|}
\hline Site & Padang & $\begin{array}{c}\text { Padang } \\
\text { Pariaman }\end{array}$ & Serang & Sumenep & $\begin{array}{c}\text { Kutai } \\
\text { Kertanegara }\end{array}$ & Gorontalo & Makassar & Bone \\
\hline $\begin{array}{l}\text { Type (City, } \\
\text { district or } \\
\text { sub-district) }\end{array}$ & $\begin{array}{c}\text { City } \\
\text { (Provincial } \\
\text { capital) }\end{array}$ & District & $\begin{array}{c}\text { District } \\
\text { (Provincial } \\
\text { capital) } \\
\end{array}$ & District & District & District & $\begin{array}{c}\text { City } \\
\text { (Provincial } \\
\text { capital) }\end{array}$ & District \\
\hline Province & $\begin{array}{l}\text { West } \\
\text { Sumatra }\end{array}$ & $\begin{array}{l}\text { West } \\
\text { Sumatra }\end{array}$ & Banten & East Java & $\begin{array}{c}\text { East } \\
\text { Kalimantan }\end{array}$ & Gorontalo & $\begin{array}{c}\text { South } \\
\text { Sulawesi }\end{array}$ & $\begin{array}{c}\text { South } \\
\text { Sulawesi }\end{array}$ \\
\hline $\begin{array}{l}\text { Island/ } \\
\text { Region }\end{array}$ & $\begin{array}{c}\text { Sumatra } \\
\text { (Western } \\
\text { Indonesia) }\end{array}$ & $\begin{array}{c}\text { Sumatra } \\
\text { (Western } \\
\text { Indonesia) }\end{array}$ & $\begin{array}{c}\text { Java } \\
\text { (Western } \\
\text { Indonesia) }\end{array}$ & $\begin{array}{c}\text { Madura } \\
\text { (Central } \\
\text { Indonesia) }\end{array}$ & $\begin{array}{c}\text { Kalimantan } \\
\text { (Central } \\
\text { Kalimantan) }\end{array}$ & $\begin{array}{l}\text { Sulawesi } \\
\text { (Eastern } \\
\text { Indonesia) }\end{array}$ & $\begin{array}{l}\text { Sulawesi } \\
\text { (Eastern } \\
\text { Indonesia) }\end{array}$ & $\begin{array}{l}\text { Sulawesi } \\
\text { (Eastern } \\
\text { Indonesia) }\end{array}$ \\
\hline $\begin{array}{l}\text { Urbanl } \\
\text { Rural* }\end{array}$ & $100 \%$ Urban & $100 \%$ Rural & $83 \%$ Rural & $88 \%$ Rural & $100 \%$ Rural & $90 \%$ rural & $\begin{array}{l}\text { 100\% } \\
\text { Urban }\end{array}$ & $93 \%$ rural \\
\hline $\begin{array}{l}\text { Ethnic } \\
\text { group(s) }\end{array}$ & Minangkabau & Minangkabau & Bantenese & Madurese & $\begin{array}{c}\text { Kutai, } \\
\text { Banjar, } \\
\text { Javanese }\end{array}$ & Gorontalo & $\begin{array}{l}\text { Makassar, } \\
\text { Bugis }\end{array}$ & Bugis \\
\hline Religion & Islam & Islam & Islam & Islam & Islam & Islam & Islam & Islam \\
\hline $\begin{array}{l}\text { Sample size } \\
\text { (households) }\end{array}$ & 221 & 221 & 206 & 213 & 215 & 204 & 209 & 207 \\
\hline
\end{tabular}

* refers to proportion of households sampled from each site 
The quantitative data collection employed a household survey. Samples of households were drawn independently. For each site, a sample size of 200 households, which was conventionally determined, was obtained through a two-stage sampling. The first stage was to select 20 neighborhood units/ or hamlets using probability proportional to size (PPS) procedure; and the second stage was to systematically select 10 eligible households from each of the selected neighborhood units.

In each selected site, a list of neighborhood units including information on the number of households per unit was secondarily obtained from the local Statistical/Planning Office. Then, for each of the selected neighborhood units, a census of households was conducted to identify eligible households. A household with at least one girl aged below 19 years was considered eligible to be listed under the survey-sampling frame. With this sampling procedure, the survey should sample 1,600 households that would scatter in 160 neighborhood units or hamlets, 8 sites, and 6 provinces.

Data regarding child FC practices and the related household variables were collected using a structured questionnaire with the mother as the respondent. Four panels of survey data were collected: (1) household members' demographic characteristics; (2) household's socio-economic characteristics; (3) mother's knowledge, opinion, and experiences regarding FC practices; and (4) child's data on FC related practices.

In the survey, a child was defined as a household member aged below 19 years and differentiated between a boy and a girl. Many itemized questions especially those related to beliefs and opinions were let open, but they were recoded into categorical values during the data processing and analysis. Field personnel were carefully recruited and trained, and the questionnaires were pre-tested and revised accordingly. Systematic data quality controls were conducted at all levels during data collection and processing activities. Data were edited and cleaned before the analysis. In the field, special efforts were initiated to directly observe and document the various practices of FC. 


\section{The Second Qualitative Study}

As a follow-up of the survey, a qualitative study was conducted again to find more explanations of the survey findings. This second qualitative study used in-depth interviews and inter-active discussions with various target audiences, including traditional and modern providers, religious leaders, and the circumcised persons as well as the parents or the grandparents. The purpose of the second qualitative study was to explore the perceived images of FC practices in relation to human, child and reproductive rights and the underlying gender and socio-cultural factors, including those behind the medicalization of the practices. There were 30 informants interviewed during the second qualitative study.

Table 3. Number of informants interviewed in the second qualitative study

\begin{tabular}{lcccc}
\hline \multicolumn{1}{c}{ Category } & $\begin{array}{c}\text { Padang/ } \\
\text { Padang } \\
\text { Pariaman }\end{array}$ & Makassar & Gorontalo & Total \\
\hline $\begin{array}{l}\text { Female midwife } \\
\text { Female traditional birth }\end{array}$ & 3 & & 4 & 3 \\
attendant & 2 & 2 & & 6 \\
$\begin{array}{l}\text { Female traditional circumciser } \\
\text { Female religious leader }\end{array}$ & 3 & 4 & 3 & 2 \\
Male religious leader & & 1 & 1 & 1 \\
Male community leader & 2 & & 2 & 1 \\
Maternity Hospital director & & & 1 & 1 \\
Mother & & 7 & 1 & 4 \\
Father & 10 & & 13 & 1 \\
Female mu'alaf & & & & 30 \\
\hline Total & & & & 1 \\
\hline
\end{tabular}




\section{FINDINGS}

\section{Characteristics of the Sampled Households}

The survey covered 1,694 households in eight different sites, representing also eight different major ethnic groups of Indonesia: Minang, Sunda, Banten, Jawa, Madura, Bugis, Makassar, and Gorontalo. Overall, the majority of the households (69\%) were located in rural areas. While households in the Padang City and Makassar City sites were all urban, 10 - 15\% of households in Serang, Sumenep and Gorontalo were located in towns (urban).

Four out of five households surveyed consisted of nuclear families. A nuclear family is defined as a family consisting of husband, wife and their children or single parent with their children. The rest of the households comprised extended families, where other relatives also lived as household members. Households among the Minang and Gorontalo ethnic groups were more likely to consist of extended families than among other ethnic groups. At each site, the average household size was 4 - 6 persons and more than $95 \%$ had a male household head. Overall, women headed only $3 \%$ of the households. In the cities, the household head was most often employed in the service sector, while in the other sites; the household heads' common occupations were as laborers, farmers, or fishermen.

Table 4. Household characteristics by sites

\begin{tabular}{|c|c|c|c|c|c|c|c|c|c|}
\hline & Padang & $\begin{array}{l}\text { Padang } \\
\text { Pariaman }\end{array}$ & Serang & Sumenep & $\begin{array}{c}\text { Kutai } \\
\text { Kertanegara }\end{array}$ & Gorontalo & Makassar & Bone & Total \\
\hline $\mathrm{N}$ & 221 & 221 & 206 & 213 & 215 & 204 & 209 & 207 & 1694 \\
\hline \multicolumn{10}{|l|}{ Residence } \\
\hline $\begin{array}{l}\% \text { Rural } \\
\text { Household } \\
\text { headship }\end{array}$ & 0.0 & 100.0 & 83.4 & 88.2 & 100.0 & 89.3 & 0.0 & 92.8 & 68.9 \\
\hline$\%$ Male & 97.7 & 97.7 & 96.6 & 97.2 & 96.7 & 97.1 & 96.6 & 96.1 & 97.0 \\
\hline \multicolumn{10}{|l|}{ Type of family } \\
\hline \begin{tabular}{l}
\multicolumn{1}{c}{$\%$ Nuclear } \\
Mean household \\
size
\end{tabular} & 86.0 & 85.1 & 91.7 & 78.9 & 97.2 & 67.6 & 67.3 & 77.9 & 81.6 \\
\hline
\end{tabular}


Household's expenditure per capita varied considerably between households and between sites. The range of household's monthly expenditure per capita as a measure of household economic disparity is particularly highest in Makasar City with more than 1 million rupiah, while in Padang City only 649 thousand rupiah and in other sites 500 to 730 thousand rupiah. Comparing between sites, Gorontalo and Bone were the poorest and Padang City and Makassar City were the wealthiest as indicated by both the average and the quintile measures of household's monthly expenditure per capita. The average of household's monthly expenditure per capita was 113 and 115 thousand rupiah for Gorontalo and Bone and 217 and 222 in Makassar City and Padang City. On the same direction, the first quintile was 48 and 53 thousand rupiah for Gorontalo and Bone and 108 and 137 thousand rupiah for Makassar City and Padang City. ${ }^{1}$

Table 5. Monthly expenditure per capita (in thousand rupiah)

\begin{tabular}{lrrrrrrrrr}
\hline & Padang & $\begin{array}{c}\text { Padang } \\
\text { Pariaman }\end{array}$ & Serang & Sumenep & $\begin{array}{c}\text { Kutai } \\
\text { Kertanegara }\end{array}$ & Gorontalo & Makassar & Bone & Total \\
\hline $\begin{array}{l}\text { Mean } \\
\text { Range }\end{array}$ & 222.1 & 117.0 & 168.5 & 161.1 & 150.6 & 113.3 & 216.9 & 115.3 & 166.1 \\
Quintile & 648.6 & 555.4 & 531.5 & 720.8 & 735.0 & 633.3 & 1075.7 & 536.4 & 1075.7 \\
$\quad$ & & & & & & & & & \\
$\quad$ Q1 (20\%) & 136.5 & 99.9 & 94.3 & 93.1 & 95.2 & 47.8 & 107.5 & 52.9 & 82.5 \\
Q2 (40\%) & 183.6 & 135.0 & 130.3 & 126.7 & 132.4 & 74.5 & 151.5 & 75.2 & 123.4 \\
Q3 (60\%) & 230.5 & 174.4 & 166.5 & 161.9 & 156.1 & 97.5 & 203.3 & 102.6 & 164.7 \\
\multicolumn{1}{l}{ Q4 (80\%) } & 286.0 & 234.2 & 221.7 & 213.3 & 189.5 & 163.5 & 312.3 & 154.0 & 228.4 \\
\hline
\end{tabular}

As expected, due to the household eligibility criterion in which only households with at least one girl under the age of 19 were included, there were fewer male than female household members, with a male : female ratio of $0.75: 1.00$.

About half of all the household members were adults and half were children. Approximately $40 \%$ of the members were under 15 years of age, and over $50 \%$ were under 20 years of age. Of the children below 19 years of age, $24 \%$ were under 5 years of age (6\% were infants), $30 \%$ were aged 5-9 years, and the remaining $46 \%$ were $10-18$ years old.

\footnotetext{
${ }^{1}$ The first quintile of household's monthly expenditure per capita for Gorontalo was 48 thousand rupiah means that $20 \%$ of households in Gorontalo have expenditure per capita less than 48 thousand rupiah.
} 
Table 6. Household members' characteristic by sites

\begin{tabular}{|c|c|c|c|c|c|c|c|c|c|}
\hline & Padang & $\begin{array}{c}\text { Padang } \\
\text { Pariaman }\end{array}$ & Serang & Sumenep & $\begin{array}{c}\text { Kutai } \\
\text { Kertanegara } \\
\end{array}$ & Gorontalo & Makassar & Bone & Total \\
\hline $\mathrm{N}$ & 1196 & 1247 & 1140 & 939 & 1020 & 1088 & 1258 & 1137 & 9025 \\
\hline \multicolumn{10}{|l|}{ Sex } \\
\hline Male & 43.2 & 46.0 & 41.4 & 39.4 & 43.3 & 43.5 & 45.0 & 42.7 & 43.2 \\
\hline Female & 56.8 & 54.0 & 58.6 & 60.6 & 56.7 & 56.5 & 55.0 & 57.3 & 56.8 \\
\hline \multicolumn{10}{|c|}{ Age of Household members (years) } \\
\hline $0-4$ & 12.0 & 13.6 & 10.9 & 11.7 & 11.9 & 10.7 & 12.6 & 13.0 & 12.1 \\
\hline $5-9$ & 15.3 & 18.0 & 16.0 & 12.6 & 13.5 & 13.1 & 13.3 & 14.1 & 14.6 \\
\hline $10-14$ & 13.0 & 14.4 & 15.4 & 10.1 & 12.5 & 14.2 & 12.2 & 15.2 & 13.5 \\
\hline $15-19$ & 11.8 & 10.7 & 11.9 & 9.9 & 11.7 & 11.0 & 11.2 & 9.4 & 11.0 \\
\hline $20-24$ & 6.3 & 4.5 & 6.9 & 6.1 & 8.1 & 7.3 & 8.1 & 8.5 & 7.0 \\
\hline $25-29$ & 5.9 & 5.3 & 7.8 & 11.3 & 10.5 & 6.4 & 8.9 & 6.3 & 7.7 \\
\hline $30-34$ & 7.7 & 7.4 & 7.2 & 11.3 & 8.4 & 9.2 & 9.5 & 8.0 & 8.5 \\
\hline $35-39$ & 9.2 & 7.7 & 8.2 & 9.9 & 8.3 & 9.7 & 7.4 & 7.8 & 8.5 \\
\hline $40-44$ & 8.8 & 5.8 & 7.2 & 6.0 & 7.1 & 7.6 & 5.2 & 5.8 & 6.7 \\
\hline $45-49$ & 4.8 & 5.5 & 3.3 & 4.4 & 2.9 & 4.6 & 3.8 & 3.9 & 4.2 \\
\hline $50-54$ & 2.3 & 3.0 & 2.1 & 3.3 & 2.5 & 1.7 & 2.9 & 3.5 & 2.7 \\
\hline $55-59$ & 1.3 & 1.8 & 1.3 & 1.4 & 1.8 & 1.7 & 1.6 & 1.5 & 1.5 \\
\hline $60+$ & 1.6 & 2.5 & 1.7 & 2.1 & 0.8 & 2.9 & 3.3 & 2.9 & 2.2 \\
\hline
\end{tabular}

The majority of household members had a low level of education. The average proportion of household members aged 10 and over who had finished junior high school or lower was $74 \%$, meaning that only $26 \%$ had finished senior high school or higher.

Table 7. Education of household members' aged 10 and over by sites

\begin{tabular}{|c|c|c|c|c|c|c|c|c|c|}
\hline Education & Padang & $\begin{array}{l}\text { Padang } \\
\text { Pariaman }\end{array}$ & Serang & Sumenep & $\begin{array}{c}\text { Kutai } \\
\text { Kertanegara } \\
\end{array}$ & Gorontalo & Makassar & Bone & Total \\
\hline $\mathrm{N}$ & 839 & 806 & 795 & 691 & 730 & 786 & 895 & 787 & 6329 \\
\hline $\begin{array}{l}\text { No school/not } \\
\text { finished elementary }\end{array}$ & 9.7 & 30.0 & 21.0 & 30.0 & 15.1 & 21.0 & 13.4 & 26.4 & 20.5 \\
\hline Finished elementary & 20.6 & 26.3 & 38.7 & 35.3 & 44.7 & 40.6 & 23.1 & 42.6 & 33.6 \\
\hline Finished junior high & 22.9 & 22.8 & 22.9 & 14.8 & 19.6 & 18.2 & 19.9 & 15.9 & 19.7 \\
\hline Finished senior high & 36.2 & 17.2 & 15.8 & 15.3 & 18.4 & 15.5 & 33.7 & 11.8 & 21.0 \\
\hline $\begin{array}{l}\text { Finished academy/ } \\
\text { university }\end{array}$ & 10.6 & 3.6 & 1.5 & 4.6 & 2.3 & 4.7 & 9.8 & 3.3 & 5.2 \\
\hline
\end{tabular}




\section{Characteristics of Mothers and Fathers}

In all sites, the average age of the mothers in the households was between 25 and 45 years, although ages ranged from under 20 to over 50 . The average level of mothers' education was low. Three-fourths (73\%) of these women had never entered senior high school, ending after junior high or before. The percentage of mothers with no school or not finished elementary school was 19\%; finished elementary $37 \%$ and finished junior high $17 \%$.

As expected, the level of mothers' education was higher in the cities than in the rural sites. Overall, fathers had higher education than the mothers with $34 \%$ having senior high school education compared to $27 \%$ of the women. Only in Bone did slightly more of the women have senior high school education than the men, though figures for both sexes were very low (under 20\%). There were notable differentials between sites in mother's educational levels, especially between the urban and the rural sites. Over $50 \%$ of mothers in Padang City had finished senior high school or more, but the figures were below $20 \%$ in Serang, Sumenep, Kutai and Bone.

Most of the mothers were identified as housewives with no gainful employment outside the home. The proportion of mothers who worked as paid workers varied between sites from 15 to $30 \%$. But, in Sumenep, the proportion was relatively high with 58\% of the mothers working as farmers or self-employed in income generating activities such as home industry for handy-crafts and crackers. 
Table 8. Parents' education, and mothers' age and occupation, by sites

\begin{tabular}{|c|c|c|c|c|c|c|c|c|c|}
\hline & Padang & $\begin{array}{c}\text { Padang } \\
\text { Pariaman }\end{array}$ & Serang & Sumenep & $\begin{array}{c}\text { Kutai } \\
\text { Kertanegara C } \\
\end{array}$ & Gorontalo & Makassar & Bone & Total \\
\hline $\mathrm{N}$ & 223 & 221 & 205 & 213 & 218 & 205 & 205 & 204 & 1694 \\
\hline \multicolumn{10}{|l|}{ Age of mother (years) } \\
\hline $15-19$ & 0.0 & 0.0 & 0.0 & 1.4 & 1.4 & 0.0 & 0.5 & 1.5 & 0.6 \\
\hline $20-24$ & 4.9 & 3.6 & 5.9 & 9.4 & 12.4 & 9.3 & 5.9 & 10.8 & 7.7 \\
\hline $25-30$ & 12.6 & 16.3 & 20.0 & 28.6 & 26.6 & 12.7 & 14.1 & 15.2 & 18.3 \\
\hline $31-34$ & 23.3 & 23.1 & 22.9 & 21.6 & 16.1 & 23.4 & 26.8 & 23.0 & 22.5 \\
\hline $35-39$ & 22.9 & 23.5 & 24.9 & 19.2 & 18.8 & 23.4 & 20.0 & 19.6 & 21.5 \\
\hline $40-44$ & 21.1 & 17.2 & 14.6 & 8.9 & 13.8 & 15.6 & 12.2 & 13.2 & 14.6 \\
\hline $45-49$ & 9.0 & 11.8 & 4.4 & 6.6 & 4.1 & 9.8 & 9.8 & 9.3 & 8.1 \\
\hline $50+$ & 6.2 & 4.6 & 7.3 & 4.2 & 7.0 & 5.9 & 10.8 & 7.4 & 6.8 \\
\hline \multicolumn{10}{|l|}{ Education of father } \\
\hline Finished junior high or less & 35.0 & 69.9 & 79.2 & 72.4 & 73.2 & 72.9 & 41.5 & 84.9 & 66.0 \\
\hline Finished senior high or more & 65.0 & 30.1 & 20.8 & 27.6 & 26.8 & 27.1 & 58.5 & 15.1 & 34.0 \\
\hline \multicolumn{10}{|l|}{ Education of mother } \\
\hline Finished junior high school or less & 41.0 & 75.6 & 87.3 & 83.6 & 87.6 & 72.7 & 54.6 & 82.4 & 72.9 \\
\hline Finished senior high or more & 59.0 & 24.4 & 12.7 & 16.4 & 12.4 & 27.3 & 45.4 & 17.6 & 27.1 \\
\hline \multicolumn{10}{|l|}{ Occupation of mother } \\
\hline Housewife & 71.3 & 64.7 & 79.5 & 42.3 & 79.8 & 72.7 & 76.1 & 84.3 & 71.2 \\
\hline Labor & 0.4 & 0.9 & 2.0 & 0.5 & 1.4 & 1.0 & 0.5 & 2.0 & 1.1 \\
\hline Farmer & 0.9 & 7.2 & 7.8 & 38.0 & 14.2 & 2.4 & 0 & 3.9 & 9.4 \\
\hline Merchant & 5.8 & 14.9 & 4.9 & 4.2 & 1.8 & 7.8 & 10.2 & 3.9 & 6.7 \\
\hline Civil servant & 15.2 & 9.0 & 2.4 & 1.9 & 0.9 & 10.2 & 3.4 & 4.4 & 6.0 \\
\hline Employee & 4.0 & 1.4 & 2.0 & 1.4 & 0.5 & 1.5 & 1.5 & 0 & 1.5 \\
\hline Entrepreneur & 1.8 & 1.8 & 1.5 & 10.3 & 0.9 & 3.4 & 6.8 & 1.5 & 3.5 \\
\hline Others & 0.4 & 0.0 & 0.0 & 1.4 & 0.5 & 1.0 & 1.0 & 0.0 & 0.6 \\
\hline
\end{tabular}

Notes: Merchant or trader that included those who have small store, vendor; entrepreneur: business owner; employee: working at private company

\section{Mothers' Perceptions and Opinions}

Almost all the mothers, except in Kutai, had heard of female circumcision (FC), and they reported themselves as being circumcised. Only $65 \%$ of mothers in Kutai stated that they had been circumcised. However, most mothers never thought that FC would have any impact on their sexuality and reproductive health. The majority of mothers said that they had watched FC practices, especially those performed on their own daughters. However, only a relatively small proportion of mothers in Kutai reported ever witnessed FC procedures. Almost all mothers at all sites gave consent for the practice of FC to be performed on their daughters. When asked whether FC has beneficial effects on women, $69 \%$ responded 'yes', and mentioned benefits including successful completion of religious 
duty, health and hygiene. Only a very small proportion of mothers felt that there were no benefits of FC and 26\% said they "do not know".

When mothers were asked about their view regarding the future of the practice of FC, the majority supported its continuation and objected to any proposed ban on FC. Only small proportion of mothers (7\%) said that they would support the ban. Even among those who would support the ban, they would support only if reasons for banning are rational, understandable, and not against religion. Nevertheless, a small proportion among those who would support the ban said that they disagreed with FC because there was no FC tradition in their families, no benefits, and so that they would just follow the government policy.

A significant proportion of mothers $(20 \%)$ even suggested social sanctions should be imposed on uncircumcised girls. Larger proportions of mothers with this view were found in Padang Pariaman and Gorontalo. Across the study sites, 30 to $96 \%$ of mothers held the opinion that FC is "a must," even for girls who have already reached the age of 10 or over.

Table 9. Mothers' opinions, by sites






\section{Reasons and Decision-makers for Female Circumcision}

Almost all of the mothers surveyed themselves reported as Islam followers. They stated that religious duty was the main reason for practicing FC. When asked about the source of such information, they said that the information came from their Islamic teachers or their parents. None of the mothers, however, could mention specific sources or statements on female circumcision if it were written in the Islamic Holy Book (Al Qur'an) or the Prophet Guidance (Hadith). At the same time, many mothers also regarded FC as an inherited tradition, with inherent cultural value independent of specific religious obligation.

From in-depth interviews with religious leaders about the basis for FC in Islamic law, we found that FC had never been an issue in their 'dakwah' and there is no concensus or 'fatwa' among religious leaders about the Islamic law or basis for FC. The law varies from one mazhab to another, from 'wajib' (obligatory), to 'sunnah' (recommended but optional), while some place it at the lowest level of religious duty. Most of religious leaders said that not many followers had ever questioned FC as a subject, and therefore they seemed to be unprepared to answer questions about FC.

In terms of who made the decision to have FC performed on female children, results of this study showed that parents made the decision together.

\section{Prevalence of Female Circumcision}

Since only households with at least one girl under 19 years of age were included, the survey encompassed more girl children $(2,660)$ than boys $(1,516)$ from the households sampled.

The survey demonstrated that circumcision among girls and boys is a universal practice in the study sites. Across the sites, among all the children aged 15-18, 86-100\% of the girls and $100 \%$ of the boys were reported already circumcised. 
Table 10. Proportion of girls circumcised by sites (\%) and by age of child at time of survey

\begin{tabular}{lrrrrrrrrr}
\hline $\begin{array}{l}\text { Age of child } \\
\text { (years) }\end{array}$ & \multicolumn{1}{c}{$\begin{array}{c}\text { Padang } \\
\text { Padang }\end{array}$} & $\begin{array}{r}\text { Pariaman } \\
\text { Serang }\end{array}$ & \multicolumn{1}{c}{ Sumenep } & $\begin{array}{c}\text { Kutai } \\
\text { Kertanegara }\end{array}$ & Gorontalo & Makassar & Bone & Total \\
\hline $0-4$ & 86.6 & 52.2 & 57.5 & 100.0 & 49.4 & 81.8 & 13.6 & 7.2 & 55.0 \\
$5-9$ & 94.6 & 89.9 & 93.1 & 100.0 & 69.0 & 98.8 & 64.1 & 70.4 & 85.2 \\
$10-14$ & 95.7 & 96.2 & 99.1 & 100.0 & 84.0 & 98.0 & 95.0 & 97.9 & 96.0 \\
$15-18$ & 100.0 & 95.5 & 100.0 & 100.0 & 86.0 & 100.0 & 100.0 & 98.3 & 97.5 \\
\hline
\end{tabular}

Table 11. Proportion of boys circumcised by sites (\%) and by age of child at time of survey

\begin{tabular}{lrrrrrrrrr}
\hline $\begin{array}{l}\text { Age of child } \\
\text { (years) }\end{array}$ & Padang & $\begin{array}{c}\text { Padang } \\
\text { Pariaman }\end{array}$ & Serang & Sumenep & $\begin{array}{c}\text { Kutai } \\
\text { Kertanegara }\end{array}$ & Gorontalo & Makassar & Bone & Total \\
\hline $0-4$ & 4.5 & 2.6 & 5.1 & 0.0 & 5.4 & 0.0 & 0.0 & 3.8 & 2.8 \\
$5-9$ & 4.5 & 3.8 & 48.4 & 35.0 & 10.2 & 4.3 & 5.6 & 6.8 & 12.9 \\
$10-14$ & 70.0 & 62.0 & 91.0 & 100.0 & 64.6 & 64.6 & 53.1 & 44.6 & 66.4 \\
$15-18$ & 100.0 & 100.0 & 100.0 & 100.0 & 100.0 & 100.0 & 100.0 & 100.0 & 100.0 \\
\hline
\end{tabular}

\section{Providers and Performing Place}

The survey confirmed that traditional birth attendants (dukun bayi), traditional circumcision practitioners (dukun sunat), and midwives were the major providers of FC services. Out of 2,215 reported FC cases, $68 \%$ performed by a traditional provider (included both the traditional birth attendants and the traditional circumcision practitioners), while the remaining $32 \%$ were performed by health care providers (HCPs), especially midwives.

TBAs played the most dominant role in providing FC services at all except three sites. In Padang City and Padang Pariaman in West Sumatra, midwives were the most common providers (89\% and 68\%), and in Makassar City, in South Sulawesi, the traditional circumcision practitioner was the most common provider (70\%). In Bone, also in South Sulawesi, the traditional circumcision practitioner also played a significant role as FC provider (almost 35\% of cases), after TBAs (almost 65\%). 
Table 12. Types of provider performing female circumcision by sites

\begin{tabular}{|c|c|c|c|c|c|c|c|c|c|}
\hline FC Provider & Padang & $\begin{array}{c}\text { Padang } \\
\text { Pariaman }\end{array}$ & Serang & Sumenep & $\begin{array}{c}\text { Kutai } \\
\text { Kertanegara }\end{array}$ & Gorontalo & Makassar & Bone & $\begin{array}{c}\text { Total } \\
\text { (All cases) }\end{array}$ \\
\hline $\mathrm{N}$ & 349 & 323 & 344 & 275 & 215 & 278 & 199 & 232 & 2,215 \\
\hline TBA & 8.0 & 29.7 & 84.3 & 76.0 & 74.0 & 98.6 & 23.6 & 64.7 & 56.6 \\
\hline $\begin{array}{l}\text { Trad. } \\
\text { provider }\end{array}$ & 0.3 & 1.5 & 1.2 & 5.8 & 5.1 & 1.4 & 69.8 & 34.9 & 11.8 \\
\hline $\begin{array}{l}\text { Midwife } \\
\text { Other }\end{array}$ & 88.5 & 67.5 & 14.2 & 17.8 & 18.1 & 0.0 & 3.0 & 0.0 & 30.2 \\
\hline HCPs* & 3.2 & 1.2 & 0.3 & 0.4 & 2.8 & 0.0 & 3.5 & 0.4 & 1.4 \\
\hline
\end{tabular}

There are several reasons why TBAs as the FC provider of choice for most people. These reasons include the cost and the physical and psychological distance. People said that compared to the modern provider, TBAs are cheaper and closer to them and TBAs are happy to provide services at home. Since FC is a tradition, the practice requires traditional procedures, including prayer, which the traditional providers can provide where HCPs cannot. In Gorontalo and Bone, medicalization of FC seems unlikely to occur in the near future, since FC is regarded as a ritual practice that only TBAs know how to do - using knowledge passed to them from previous generations of TBAs in their families. The involvement of a TBA is one of the "must" criteria for the legitimate practice of FC. Several respondents in Makassar said they would not ask a doctor to do FC because he or she is not a traditional provider.

Medicalization of FC, or FC procedures performed by midwives, has already occurred in Padang and Padang Pariaman, and is underway in other sites, including Serang, Sumenep and Kutai Kartanegara. In Padang Pariaman, traditional birth attendants performed only $30 \%$ of the female circumcisions among the girls in the sample, not as much as they used to perform in the past. Reasons cited for choosing a midwife included: practicality, few requirements, and better clinical skill. Midwives are regarded as knowing more details of the relevant anatomy and biology, so that if anything were to go wrong, he or she could handle it quickly and competently. Plus they are more equipped with sterile circumcision tools than TBAs. Besides, midwives did not charge more expenses than TBAs, and they are accessible - meaning they are willing to perform FC at their home, or at the Community Health Center (puskesmas) or when the child is taken for immunizations. For the sake of efficiency, the family usually uses the same midwife who assisted the birth of child. 
Where the medicalization of FC is already widespread, FC procedure mostly took place in the midwife's own private practice, or at the puskesmas, or at the client's home. Although FC is a non-therapeutic procedure, several hospitals or maternity clinics offer this as part of the maternity service package. Those who still chose a traditional provider stated that they believed the procedure more sacred and perfect ( $a f d o l$ ) in the eyes of God. And, specific wishes could be fulfilled, for example including a chicken and curry powder will to ensure that the child would later become a good cook. A TBA usually did better than the midwives.

\section{Age at Circumcision}

Age at circumcision for girls varied from newborn up to 9 years of age. In Padang City, Sumenep, and Kutai, the majority of mothers mentioned newborn and infancy as the ideal time for FC, while in Makassar and Bone, the majority cited older ages, between 5 and 9 years. It was noted, however, that age at circumcision varied widely at each site. In Padang Pariaman and Serang, the practice was sometimes done at a very early age, and sometimes between age 1 and 4 years. In Sulawesi, age at circumcision for females was generally much older. Most of the girls circumcised in Gorontalo had undergone the procedure between the ages of 1-4 years, while in South Sulawesi (Makassar and Bone) it was mostly undertaken at older ages, especially between the ages of $5-9$ years, but sometimes even over the age of 10 (see Table 13).

Table 13. Age at female circumcision by sites

\begin{tabular}{lccccccccc}
\hline \multirow{2}{*}{ Age at FC } & Padang & $\begin{array}{c}\text { Padang } \\
\text { Pariaman }\end{array}$ & Serang & Sumenep & $\begin{array}{c}\text { Kutai } \\
\text { Kertanegara }\end{array}$ & Gorontalo & Makassar & Bone & $\begin{array}{c}\text { Total } \\
\text { (All cases) }\end{array}$ \\
\cline { 2 - 11 } & \multicolumn{1}{c}{349} & 323 & 344 & 275 & 215 & 278 & 199 & 232 & 2,215 \\
\hline$<1 \mathrm{yr}$ & 87.1 & 53.3 & 35.5 & 98.5 & 70.7 & 20.9 & 12.6 & 0.0 & 49.8 \\
$1-4 \mathrm{yrs}$ & 10.9 & 31.9 & 53.8 & 1.5 & 17.7 & 78.1 & 25.6 & 25.9 & 31.4 \\
$5-9 \mathrm{yrs}$ & 2.0 & 14.9 & 10.8 & 0.0 & 11.6 & 0.7 & 54.8 & 72.0 & 17.8 \\
$10 \mathrm{yrs}+$ & 0.0 & 0.0 & 0.0 & 0.0 & 0.0 & 0.4 & 7.0 & 2.2 & 0.9 \\
\hline
\end{tabular}

Midwives or TBAs performed most of the circumcisions on newborns, usually just after delivery. On the other hand, the traditional circumcision practitioners more often performed circumcisions at later ages. 
Although the age of female circumcision varies, the practice serves the same function of transferring female gender identity to the child. When performed at early ages (infancy and early childhood), the practice is also commonly combined with ear piercing (tindik) or ceremonies of early childhood (rites of passage), such as hair cutting, aqiqah, etc. When performed at later ages, especially after 5 years old, the children are expected to remember the experience and integrate this into their concept of their sexual and gender identity. Circumcision at later ages in South Sulawesi is associated with development of the girl's ability to read the syahadat (the testimony or declaration of faith by which the one who utters it enters into the fold of Islam).

\section{Types of Female Circumcision}

The survey found reports on the practice of various types of FC procedures included rubbing and scraping, stretching, pricking and piercing, incision and, finally, excision. Based on the WHO classifications, these practices can be categorized into "Type I - Excision," and "Type IV - Unclassified," this latter encompassing all the other procedures occurring at the study sites. As shown in Table 11, among all these procedures, incision (Type IV) was found to be the most common type of FC at four of the eight sites (Serang 75\%, Kutai 63\%, Gorontalo 55\% and Bone 72\%). A high incidence (more than half of cases) of Type I FC (excision) was found in Padang City and Padang Pariaman. However, a significant proportion of Type I FC was also found in Sumenep in Madura $(22 \%)$ and Bone, in South Sulawesi (16\%). However, the procedure of only rubbing and scraping was the most common form of FC in Sumenep (42\%), as it was in Makassar (74\%).

Table 14. Proportion of each type of female circumcision performed by site

\begin{tabular}{|c|c|c|c|c|c|c|c|c|c|}
\hline Type of FC & Padang & $\begin{array}{l}\text { Padang } \\
\text { Pariaman }\end{array}$ & Serang & Sumenep & $\begin{array}{c}\text { Kutai } \\
\text { Kertanegara }\end{array}$ & Gorontalo & Makassar & Bone & $\begin{array}{c}\text { Total } \\
\text { (All cases) }\end{array}$ \\
\hline $\mathbf{N}$ & 192 & 224 & 263 & 149 & 107 & 142 & 108 & 122 & 1307 \\
\hline $\begin{array}{l}\text { Rubbing \& } \\
\text { scraping }\end{array}$ & 12.0 & 14.7 & 17.9 & 41.6 & 26.2 & 21.1 & 74.1 & 11.5 & 24.3 \\
\hline Stretching & - & - & - & 2.7 & 0.9 & 23.2 & 0.9 & - & 3.0 \\
\hline $\begin{array}{l}\text { Pricking \& } \\
\text { piercing }\end{array}$ & - & - & 2.7 & 0.7 & 1.9 & 0.7 & 3.7 & - & 1.1 \\
\hline Incision & 37.5 & 30.4 & 74.9 & 33.6 & 62.6 & 54.9 & 21.3 & 72.1 & 49.2 \\
\hline Excision & 50.5 & 54.9 & 4.6 & 21.5 & 8.4 & - & - & 16.4 & 22.4 \\
\hline
\end{tabular}


In-depth interviews with the traditional FC practitioners in Makassar indicated that the procedure typically involves scraping the clitoris once (or more times) with no bleeding. However, there were those who insisted that circumcision must be accompanied by bleeding to make it official, but usually no tissue is removed. In Gorontalo, besides incising, stretching was also performed in $23 \%$ of the FC cases.

Mothers were asked to report on the occurrence of bleeding, tissue removal and crying by their child at the time of circumcision. Bleeding and also tissue removal was reported in over half of FC cases. It was noted that a particularly small proportion of FC cases in Makassar reportedly involved bleeding and tissue removal, compared to other sites. The majority of mothers, except in Makassar and Bone, reported that their child cried during the procedures. Further, there was a much higher reported incidence of bleeding, tissue removal and crying by the child among the FC cases reportedly involving incising and excising than among those circumcision involving rubbing and scraping, stretching, and pricking and piercing, suggesting that mothers had provided accurate information, consistent with that of the providers.

Table 15. Percentage of mothers reported bleeding, tissue removal and child crying

\begin{tabular}{|c|c|c|c|c|c|c|}
\hline & \multicolumn{5}{|c|}{ Type of FC Procedure } & \multirow{2}{*}{$\begin{array}{c}\text { Total } \\
\text { All forms }\end{array}$} \\
\hline & $\begin{array}{l}\text { Rubbing \& } \\
\text { Scraping }\end{array}$ & Stretching & $\begin{array}{l}\text { Pricking \& } \\
\text { Piercing }\end{array}$ & Incision & Excision & \\
\hline $\begin{array}{l}\text { Number of mothers } \\
\text { witnessing the FC of their } \\
\text { daughters } \\
\% \text { of those who reported } \\
\text { bleeding, tissue removal } \\
\text { and crying }\end{array}$ & 317 & 25.6 & 13.3 & 643 & 293 & 1307 \\
\hline
\end{tabular}

As may be expected, use of antiseptic and also other topical preparations was commonly associated with incision and excision forms of FC. For the antiseptic, the circumcisers usually use Betadine or alcohol. For the traditional topical preparation, including 'sirih' leaves (chewed by the practitioner), cooking oil, turmeric, a mixture of gambir and sirih, and sometimes kencur (galangale) and ginger, this was usually smeared onto the circumcised area. 
Table 16. Use of topical preparation by types of FC

\begin{tabular}{lcccccc}
\hline $\begin{array}{l}\text { Topical } \\
\text { preparations }\end{array}$ & $\begin{array}{c}\text { Rubbing \& } \\
\text { Scrapping }\end{array}$ & Stretching & $\begin{array}{c}\text { Used for } \\
\text { Pricking \& } \\
\text { Piercing }\end{array}$ & Incision & $\begin{array}{c}\text { Total } \\
\text { Excision }\end{array}$ & $\begin{array}{c}\text { Eye- } \\
\text { witnessed } \\
\text { cases) }\end{array}$ \\
& 317 & 39 & 15 & 643 & 293 & 1307 \\
\hline Not given & 73.2 & 79.5 & 86.7 & 58.6 & 25.3 & 55.6 \\
Antiseptic & 0.0 & 0.0 & 13.3 & 28.6 & 72.4 & 33.7 \\
$\begin{array}{l}\text { Other modern } \\
\text { medicine }\end{array}$ & 0.6 & 0.0 & 0.0 & 2.0 & 0.0 & 1.1 \\
Traditional & 10.4 & 0.0 & 0.0 & 8.7 & 1.7 & 7.2 \\
Jampi-jampi & & & & & & 0.2 \\
(“holy"water) & 0.0 & 0.0 & 0.0 & 0.3 & 0.0 & 2.1 \\
Do not know & 2.2 & 20.5 & 0.0 & 1.7 & 0.7 & 0.7 \\
\hline
\end{tabular}

\section{Providers and Types of Circumcision}

Analysis of the study findings showed that traditional providers tended to perform Type IV ("Unclassified"), while modern health care providers (HCPs) tended to perform Type I FC. The majority of the FC cases performed by traditional circumcision practitioners (dukun sunat) used the procedures of rubbing and scraping (56\%), while $38 \%$ performed incision (without removal of tissue). TBA-performed FC cases mostly involved incision (62\%), while a quarter of cases were by rubbing and scraping. Approximately 5\% of FC cases performed by each type of traditional provider involved excision of tissue. In comparison, most of the FC cases where midwives provided services, used excision (57\%), and incision was also common (31\%), while only one-tenth were rubbed and scraped (see Table 17).

Table 17. Providers and type of female circumcision among eye-witnessed cases, by sites

\begin{tabular}{lcccccc}
\hline \multirow{2}{*}{ Eye-witnessed cases } & \multicolumn{9}{c}{ Type of FC Procedure } & \multicolumn{1}{c}{ Total } \\
\cline { 2 - 6 } & $\begin{array}{c}\text { Rubbing \& } \\
\text { Scraping }\end{array}$ & Stretching & $\begin{array}{c}\text { Pricking \& } \\
\text { Piercing }\end{array}$ & Incision & Excision & All forms \\
N & 317 & 39 & 15 & 643 & 293 & 1307 \\
\hline TBA & 26.8 & 5.0 & 0.8 & 61.8 & 5.6 & $746(100 \%)$ \\
Traditional practitioner & 56.3 & 0.8 & 0.0 & 38.3 & 4.7 & $128(100 \%)$ \\
Midwife & 10.1 & 0.2 & 1.4 & 31.2 & 57.0 & $414(100 \%)$ \\
Other HCPs* & 15.8 & 0.0 & 15.8 & 21.1 & 47.4 & $19(100 \%)$ \\
\hline
\end{tabular}

*Including: medical doctor and nurse 


\section{Procedures}

Providers usually used scissors or a knife as their tool for performing circumcision.

Out of 2,215 reported cases, the most widely identified cutting instrument or tool was a penknife (55\%), followed by scissors (24\%), bamboo knife or razor blade (5\%) and needle (1\%). The remaining $15 \%$ mentioned "other" types of instruments, such as metal coins, turmeric (kunyit) or the fingers and fingernails of the circumciser. Among the sub-set of cases where eye-witness reports are available $(\mathrm{N}=1307)$, the distribution of the types of cutting instruments used differs only slightly (see Table 18).

Table 18. Type of cutting instruments (With-and Without Probing)

\begin{tabular}{lcc}
\hline & $\begin{array}{c}\text { All reported cases } \\
\text { (without probing) }\end{array}$ & $\begin{array}{c}\text { Eye-witnessed cases } \\
\text { (with probing) }\end{array}$ \\
\cline { 2 - 3 } $\mathbf{N = \mathbf { 2 2 1 5 }}$ & $\mathbf{N = 1 3 0 7}$ \\
\hline Cutting instrument: & & 62.1 \\
Pen knife & 54.9 & 29.3 \\
Scissors & 23.9 & 5.3 \\
Bamboo knife / razor blade & 5.4 & 1.1 \\
Needle & 0.9 & 2.1 \\
Others* & 2.4 & 0.0 \\
Do not know & 12.6 &
\end{tabular}

However, apparently the cutting instruments were not always used for actual cutting. Among the eye-witnessed FC cases where a penknife was used, only 66\% involved incising or excising, while in the remaining cases it was used for rubbing and scrapping. But where scissors were used, cutting was almost always involved, including incision (22\%) and excision (72\%). Bamboo knives or razor blades were used for rubbing and scraping in $46 \%$ of cases and for incision in 54\%. Needles were mainly used for pricking and piercing types of circumcision. 
Table 19. Types of cutting instruments, by types of FC procedure, among eyewitnessed cases $(\mathrm{N}=1307)$

\begin{tabular}{lcccccc}
\hline \multirow{2}{*}{ Instrument } & \multicolumn{3}{c}{ Type of FC procedure } & \multicolumn{1}{c}{ Total } \\
\cline { 2 - 7 } & $\begin{array}{c}\text { Rubbing \& } \\
\text { scraping }\end{array}$ & Stretching & $\begin{array}{c}\text { Pricking \& } \\
\text { piercing }\end{array}$ & Incision & Excision & All forms \\
\hline Penknife & 29.9 & 3.8 & 0.5 & 63.8 & 2.0 & $812(100 \%)$ \\
Scissors & 5.5 & 0.3 & - & 22.2 & 72.1 & $383(100 \%)$ \\
Bamboo knife / & & & - & 53.6 & - & $69(100 \%)$ \\
razor blade & 46.4 & - & 73.3 & & - & $15(100 \%)$ \\
Needles & 26.7 & & & 10.7 & 3.6 & $28(100 \%)$ \\
Others* & 60.7 & 25.0 & & & & \\
\hline
\end{tabular}

\section{Types of Provider and Cutting Instruments}

There was a notable tendency among the modern HCPs to prefer scissors as the FC tool (used in $77 \%$ of cases of FC by midwives), while the traditional providers most often used a penknife (82 - 91\% of FC cases). Across the sites, smaller proportions of modern providers used penknives and smaller proportions of traditional providers used scissors. Favoring the use of a penknife, traditional providers used it often for rubbing and scraping (16\%) and stretching (4.4\%), rather than for incision or excision. On the other hand, modern providers using scissors were more likely to perform incisions or excisions (94\%).

One midwife in Padang described how she usually cuts the clitoris, either directly or by pinching it first with tweezers and then cutting the tip with scissors. Another said that she only scratches the clitoris. The tools used by midwives and doctors include: scissors (surgical scissors, straight and curved) and tweezers, while the traditional providers generally use a small knife or razor blade. One described how he uses a thorn from a pandan leaf, known as sembilu (blade). 
Table 20. Providers by instruments utilized, among eye-witnessed cases of female circumcision $(\mathrm{N}=1307)$

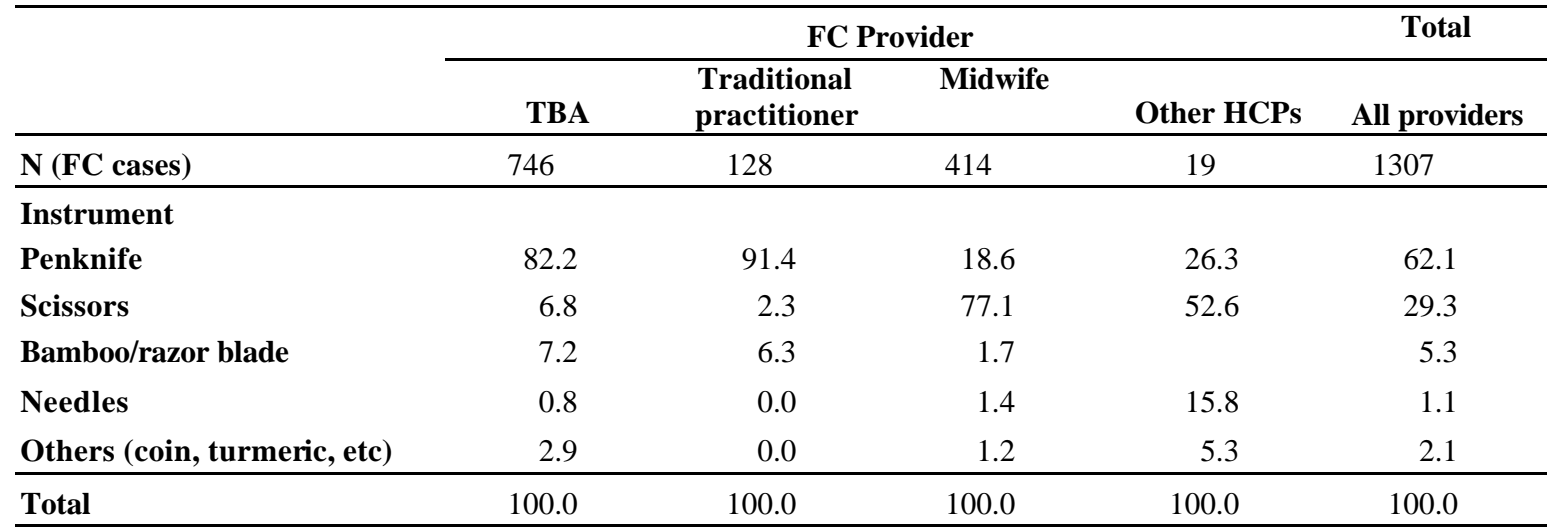

\section{Part of the Genitalia Affected by Circumcision}

Across the sites, almost half of the mothers did not directly witness the practice of FC on their daughters. Fear, or not wanting to see their child being "cut", was the most frequently cited reason for not watching or attending. Of the mothers who directly witnessed the procedures, $82 \%$ said there was actual "cutting". 2 Among the mothers who did not witness the practice, over half said they 'do not know' whether there was cutting.

Table 21. Percentage of mothers who reported actual cutting in FC of their daughters

\begin{tabular}{lrrr}
\hline & $\begin{array}{c}\text { Mothers who } \\
\text { directly witnessed } \\
\text { the procedure }\end{array}$ & $\begin{array}{c}\text { Mothers who did not } \\
\text { directly witness the } \\
\text { procedure }\end{array}$ & $\begin{array}{c}\text { Total (all mothers of } \\
\text { circumcised } \\
\text { daughters) }\end{array}$ \\
\hline Yes - there was actual cutting & 82.1 & 40.1 & 65.0 \\
No - there was no actual cutting & $(1073)$ & $(364)$ & $(1437)$ \\
& 14.9 & 7.6 & 35.0 \\
Do not know & $(195)$ & 52.3 & $(264)$ \\
& 3.0 & $(475)$ & 23.2 \\
\hline Total & $(39)$ & 100.0 & $(514)$ \\
\hline
\end{tabular}

The majority of mothers cited 'clitoris' (using words 'jelik', 'inti', 'kelenntit', 'cikiciki', 'cenil') as the part of the genitals that was affected during their daughters' circumcisions. Nevertheless, 15 to $50 \%$ of the female children circumcised in Sumenep, Kutai, Gorontalo, and Makassar reported no physical injury on the genital part on the basis of no blood and no wound. (Tables 21)

\footnotetext{
${ }^{2}$ Cutting means including the incision (without tissue removal).
} 


\section{What - and How Much - is Cut Off or Removed from the Body?}

The wide variation in procedures, providers and tools involved in FC makes it difficult to generalize about the practice, including what, if anything, is removed from the girls' genitalia.

\section{Traditional procedure}

In almost all sites, we found no consistency in the reported shape, size and color of the removed part. It was variously described as round, sharp-edged, a grain of rice, a piece of a grain of rice (menir), guava seed, sand, a nail clipping, green bean, and a head of needle, and komedo (black-hat on the nose). Mostly the size or amount is described as "a little" or "small," with no further explanation. The color of what was cut or removed was described variously as white, red, light red, pink, earthy red, white with blackness, brownish, or the same color as the skin or flesh. It was very difficult to verify what and how much tissue was actually cut or removed. In Makassar and Gorontalo, the act of cutting was done under a sarong or cloth generally and obscured from all eye-witnesses, only the practitioner knows exactly what part and how much (if any) of the genitalia flesh was cut or removed, or whether only some skin was scraped off, or some dirt rubbed off.

In Makassar, FC usually is purely symbolic, although $25 \%$ of cases involved incision, pricking or piercing (see Table 14). Observation indicated that typically the procedure is only to "clean" the labia minora by scraping with a knife "to remove the dirt" ('mengerik'), with no bleeding. Sometimes the procedure includes cutting a cock's comb and wiping a little of the resulting onto the clitoris. However, there are those who believe that circumcision must be accompanied by bleeding to make it official, but usually no tissue is removed. During in-depth interviews, some traditional circumcisers said that FC involves cutting the tip of the clitoris, a piece the size of $1 / 4$ gabah (grain of rice) or the size of daki (a roll of dirty skin rubbed off from the body). One informant said that the practitioner does not even look at the genitalia at all, but rubs the part a little before doing the circumcision. Before use, the informants said that the tools are usually washed with water (sometimes soaked in sirih water), hot water, soap or alcohol and then cleaned and dried with cotton wool, cloth or sterile bandage mesh. 
In Gorontalo, the local term for FC is 'mongubingo' which means, "to pinch," while male circumcision, which clearly involves cutting, is locally termed 'moluhuna' which means "cut". According to one dukun, the FC process does not involve cutting but squeezing between a finger and the blade of a knife the part that is deemed haram (unholy). However, although FC is not termed cutting, the traditional figureheads (tokoh adat), as well as parents, stated that there must be a part taken, if only a very tiny piece, which is "blood red", but not actually flesh. The circumcision must also leave a wound, based on the concept of titipan darah, or blood, which must come out. One observer in Gorontalo saw that the part that had supposedly been cut off was actually a grain of rice, while the attendant explained that the cut part was not the flesh of the clitoris but something that looks "like white rice at the upper part of urination hole". A self reported 23 year old muallaf (term for someone who enters Islam), said that the procedure involved use of a penknife and there was a cutting, yet she only felt a pinch and there was no blood, but she felt a stinging pain (perih) for about a week afterwards. She was circumcised at 18 years old, before she was married her Muslim husband.

The circumcision method used depends on the tribal origin of the parents; although the current residence is far from parent's place of origin. A Sundanese informant with a "sunda" way used a needle to dislodge the tip of the clitoris until mucous comes out. While a Gorontalo informant said that FC included scraping of genitalia (the size of a pepper corn) and then the knife would be stabbed into a lemon.

In Sumenep (Madura), an observation indicated that the traditional practitioner did not clean the genitalia or the tools, but pulled the labia majora until the clitoris protruded and then directly scraped the top part of the clitoris with a kitchen knife, each side of which was held with a slice of turmeric root. It was seen that the part taken looked like a small piece of white fat on the knife, and no bleeding was observed.

In Padang Pariaman, the traditional circumciser said she only cuts a very tiny piece (like the very end of a leaf) just so she is able to show to the family that circumcision has been performed. Another traditional circumciser reported using a scissor she received from the midwife with little bleeding. The procedure was usually done at early morning to avoid too much bleeding. 
In Serang - Banten, a traditional circumciser described FC procedure by using a coin as a base and finger to press and pull the clitoris and then cut a little the tip of the clitoris with the penknife. It was not clear whether the little tissue removed was a real tip of clitoris or dirt spotted in the clitoris.

\section{Modern procedure}

One midwife in Padang City described the FC by pinching directly with tweezers and then cutting the tip of the clitoris with scissors. According to chief of IBI (Indonesian Midwife Association) in Padang Pariaman, issues concerning female circumcision were addressed at the 1998 IBI National Congress in Bali, which agreed to stop genital cutting in the FC practice. Since then, the IBI in Padang Pariaman has disseminated this agreed result to its members. However, observations and interviews have indicated that the common practice of 'genital' cutting in FC is still noted. In Padang Pariaman and also in Serang, the observers witnessed one midwife do actual cutting of clitoris with scissors in female circumcision. But, another observer in Serang witnessed a midwife doing FC by gouging out/levering up (mencungkil) the edge of clitoris with a curve-needle without removing the genital tissue.

One midwife in Padang Pariaman admitted cutting the genital part as a proof the girl has already been 'formally' circumcised. Family can request the proof through the removed tissue to be buried. If there is no proof her Islam would not be considered 'formal'.

In Makassar, it was reported that one medical doctor uses scissors to cut the tip of the clitoris, not removing any flesh but just thick milk-like fluid from the tip.

According to direct observations during a FC mass event in Bandung-West Java, that was organized by Assalam Foundation and involved almost 100 girl children and a few girl adolescents, the observers did witness actual cutting of the clitoris by the midwives and the certified circumcisers. A tiny piece of the tip of the clitoris (with varying size) was cut with scissors and little blood appeared on the cutting. The certified circumciser dabbed the bleeding with a cotton swab soaked with betadine. One male doctor at Assalam said that FC affects the preputium, not the clitoris, and usually without genital tissue removal. However, he also said that tissue removal could happen if the preputium is wide or hard as cleaning becomes difficult. If not circumcised or opened, the 
woman's clitoris will become 'tense' and affect the genital bone. Another doctor said he never learned the FC, but there has been no specific guidance on the procedure. Doctors or midwives usually learn from their seniors. The guidance is available only for male circumcision.

\section{Types of Payment}

Mothers could give money or payment in kind, or sometimes both, to the providers. Not very many mothers gave in kind payments, except in Bone, where a significant proportion of mothers used in-kind payment (non-monetary). Mothers tended to give money to the midwife, but used a combination of money and in kind payment to traditional providers. Over half of mothers paid less than 10,000 rupiah, and a third (34\%) paid between 10,000 and 50,000 rupiah for the procedures.

\section{Celebrations during Female Circumcisions}

Overall, $54 \%$ of the female circumcision cases were accompanied by celebrations. Only in Padang City and Padang Pariaman, the proportions of mothers who reported conducting celebrations were much smaller. Among those who celebrated female circumcision, almost half spent between 100,000 and 500,000 rupiah, while others paid less.

In general, the ceremony was perceived as a society's recognition to the transformation from a girl child to her womanhood. For example, 'mandi lemon' in Gorontalo is bathing of the girl in 'acid' (lemon) water to symbolically weaken the female's sexual libido, which according to the society must be controlled. An activist of the BKOW (Forum of Women's Organizations) in Padang reported a common belief that the more blood shed during FC, the better the social status after the girl gets married (status of the husband).

A 'makatte' (FC provider in Makassar) said that FC is used as a ceremonial ritual for getting blessings in relation to her future prospects as a wife. For example, the symbolic cutting of the cock's comb was wrapped in sirih leaf and wrapped again in banana leaf, and then stored in the ridge of the house-roof. Because, local people belief that such a practice would discard any bad luck of the circumcised girl in the future. Another practice was scraping the outer part of the clitoris and wrapped it with cotton wool 
that has dripped with the blood from cutting the cock's comb, and then wrapping in banana leaf and had to be stored by the child's mother in the house-roof. This practice was believed as wishing the girl to meet a good husband later. Another mother said that the tissue from her girl child's circumcision was buried underneath a tree as a wish that the child would gain a long life. 


\section{CONCLUSIONS AND RECOMMENDATIONS}

Too much of review and literature studies about FC are based on generalizations although they are presented as empirical facts. But the findings from this study are valuable as well as credible because they are evidence-based on empirical on-site observations.

Community level findings indicate that in general, Muslim communities support the continuation of FC practice, because they perceive it as both a societal custom or tradition, and a religious duty. Unless there is a concerted intervention effort aimed at eradication, the continuation of FC in Indonesia is assured since parents continue to support, demand, and buy these services for their daughters. Thus far, there has been no efforts at prevention either in terms of attempts to change community values or to make the practice illegal. Religious leaders want the practice of FC to be continued indefinitely, because of their interpretations of its religious significance. Around $92 \%$ of the families visited for the survey expressed support for the continuation of FC for their girl children and future grandchildren. Over two-third of mothers (69\%) perceived that FC has beneficial effects on their girl children, and only 5 percent admitted to believing that there are no benefits to FC.

Over twenty years ago, in August 1982, the WHO called for attention to the issue of the medicalization of FC with a formal statement of opposition, advising that "under no circumstances should FC be performed by health professionals or in health establishments" (WHO, 1998). A review of national policies showed that Indonesia's Ministry of Health has not taken any firm action to prevent the medicalization of FC despite this fact. Indeed, it is chilling that findings of the study presented in this paper have shown that extensive medicalization of FC has already occurred in some parts of the country and is underway in others. Many midwives have begun to market FC as part of a birth delivery package, with the service being offered to the parents right after delivery of a baby girl. The 
availability of FC among the menu of services available at birthing clinics puts additional pressure on young and inexperienced parents, who may not have made a decision about FC for their daughter or have any religious knowledge on the subject, to end up selecting this option so as to be seen to embrace Muslim customs. Specifically, medicalization of FC has clearly been established in Padang $(91.7 \%$ of 349 observed cases) and Padang Pariaman (68.7\% of 323 observed cases), while there is an increasing tendency towards this medicalization in Kutai Kertanegara (20.9\% of 215 observed cases), Sumenep in Madura island (18.2\% of 275 observed cases), and Serang (14.5\% out of 344 observed cases). Additional observations made in Bandung (As-Salam) gave a similar impression of growing medicalization. Unlike male circumcision, the procedures for FC are not covered by the formal midwifery training curriculum issued by the Ministry of Health. Therefore, whatever procedures midwives use in their practice of FC are mostly copied from watching senior midwives perform it, or by asking a traditional circumcision practitioner (dukun sunat) or traditional birth attendant (dukun bayi), and these procedures are not medically endorsed. The dangers of FC increase with the medicalization of FC, since, as found in this study, midwives tend to use scissors instead of penknives and more often use them for cutting of the clitoris (incision and excision), where traditional providers more often use penknives for more symbolic acts of scraping or rubbing, and sometimes pricking or piercing the outer part of clitoris.

FC practices can be divided into two main groups: "symbolic only" types where there is no incision or excision, accounting for about $28 \%$ of all the cases of FC in the study for which an eye-witness account was available, and "harmful" forms, involving incision and excision, accounting for the remaining $72 \%$ of the cases. Community members surveyed defended the practice as an important tradition which is based on the belief that FC bestows purification on the girl (in part by preventing girls from becoming over-sexed as adults) and gives parents the satisfaction of having fulfilled their religious obligations. In the name of religion, 
this practice claims legitimacy, while at the same time it clearly implies that the value of a girl-child is less than a boy, saying that girls require FC to preserve their chastity, purity, hygiene and to later provide greater sexual pleasure to husbands. These notions are insupportable as they can easily lead us to rationalize gender inequality when we are invited to assume that uncircumcised women will have uncontrollable sexual desire, and be unclean or haram.

Parents and religious leaders alike were found to have no significant knowledge on the formal links between FC and Islam. They could not answer the question of why no daughter of the prophet Muhammad, Peace Be upon Him was circumcised. We can conclude that the practice of FC in Indonesia is essentially a tradition which has been passed from one generation to the next with little questioning about its meaning or its basis in Islamic history or law. Many adhere to, and pass down, this tradition simply because elders and grandparents wish to preserve this practice in the younger generations. They were convinced that FC is an obligation under Islam, but most admit not knowing which Islamic law or verse indicates the requirement for FC.

This study did not succeed in finding enough evidence to answer the research question of whether or not girls who have undergone FC are at risk for the loss of sexual function or for related reproductive problems or health complications. The study findings did not reveal any clear immediate or long-term physical or psychological complications of FC for girls or women. However, direct observation of procedures showed that FC practice in Indonesia certainly involves pain and real genital cutting in about three-quarters of cases. This evidence, and the fact that it is done without the consent of the girl and without clear health benefits or religious mandate is enough to classify this act as a violation of human rights, specifically children's rights and women's sexual and reproductive rights. The practice of FC in Indonesia can therefore be said to violate the rights of the child as guaranteed under the Convention on the Rights of the Child, which was ratified by Indonesia in 1990. 
The common argument that FC, if performed under hygienic and medically controlled conditions and by a trained medical provider, is the lesser of two evils compared to the greater risk of severe complications from unhygienic procedures performed by traditional providers, is also not acceptable. Not only is FC a human choice rather that a biological inevitability or imperative, such as birth is, it is also potentially harmful to an otherwise healthy child. Besides being unethical for these reasons for a health professional to provide this service, there is also evidence from this study that medical practitioners (mainly midwives) providing FC tend to perform more invasive forms of the practice, more often involving incision and excision (68-88\% of cases, compared to $43-67 \%$ of cases performed by traditional providers). In conclusion, to paraphrase a statement of the WHO, it is difficult to find a medico-legal justification for the practice of FC on girl-children by health professionals in Indonesia. There should be a concerted effort by all donor agencies and implementing organizations working in the fields of both women's rights and public health to translate the WHO's August 1982 statement of opposition to the medicalization of FC into concrete, community-based action. This should start with the opening of dialogue in Indonesia among representatives of USAID, the WHO, UNICEF, UNFPA, and the World Bank's District Health Project about the potential for collaboration on immediate promotion and socialization of messages aimed at stopping the medicalization of FC, by making this issue an added component within current health intervention projects.

Based on the study results, it is strongly recommended that these key donor agencies should join together in putting pressure on the Ministry of Health - as the responsible branch of the government's apparatus - to protect girls and women's sexual and reproductive rights. The State Ministry for Women's Empowerment should express a strong demand to hasten the issuance of health policy aimed at stopping the medicalization of FC, specifying that it must not be performed by health professionals or offered as part of a birth delivery package in maternity clinics or hospital establishments. The State Ministry for Women's Empowe rment, the Ministry of Health and the Ministry of Social Affairs, together with the 
Indonesian Midwives Association (IBI) and the Indonesian Pediatricians Association (IDAI), can put the findings of this study to immediate use in developing policy as well as primary messages as part of a national campaign to ban the practice of FC in health facilities or at people's homes performed by health providers.

All available mass communication systems and media of popular culture should be utilized for the dissemination of information and messages in an accessible form, making clear the fact that this practice violates human rights and has no clear doctrinal support in the primary text of Islamic law. Such community education by creative media strategies can encourage dialogue in a non-threatening way. While policy and law enforcement can address the issue from the side of reducing the available supply of medical providers for the practice, these mass education efforts should focus on reducing the demand for FC from the community, which can facilitate consensus building and collective decision-making in support of abandoning the practice of FC. The fact that FC is not obligatory under Islamic law can be emphasized in a mass media campaign and in midwifery training curricula. Information dissemination in both Bahasa Indonesia and English can range from seminars and publications, to electronic (websites), mass print media (newspapers and magazines), pictorial fact-sheets, and folk media (drama, dance, music and puppet shows) aimed at reaching audiences at all levels of society and in all pertinent locations. It is crucial that the information should reach the rural poor and community leaders with low education, fathers, mothers, and also the young men and women who will be the parents of girl children.

Lessons learned from other countries show that efforts to eradicate FC are not effective and success is not sustainable if only one aspect of FC is addressed such as only the legal framework or only the health care providers - in isolation from societal and cultural determinants. Since culture is a social construction that is highly colored by the opinions and values of males and of religious leaders, successful strategies must involve messages that reach diverse audiences, including 
men, opinion leaders, religious leaders and policy makers. Traditional birth attendants, health practitioners and women must also be targeted. Furthermore, an anti-FC campaign that is initiated by outsiders can be perceived as an attack on culture and tradition, instead of on the harmful practice. Thus, research and intervention efforts should focus on designing effective local strategies to incorporate the potential involvement of existing community-based assets, such as local NGOs and women's religious organizations (such as Fatayat NU and Muhammadiyah) whose good work in reproductive health and human rights has been documented, to counter arguments made by FC adherents. The cooperation and assistance of these grassroots women's NGOs should be sought in the development of a broad-based community education campaign to promote discussion about FC and encourage local leaders to speak out against the practice. Progress should be monitored and evaluated to assess the effectiveness of the educational interventions, including materials and messages - so that efforts do not stop at raising awareness only but persistently make progress towards changing behavior, preventing and eventually eliminating the practice of FC.

The end-goal is to have an empowered community that freely, knowledgeably, and autonomously decide how best to prohibit FC locally, giving explicit value to the objective of improving the quality and safety of woman's sexual and reproductive lives. An effective role that NGOs can play is as facilitators, training and supporting individuals to become agents of change for themselves and their communities. Thus individual key community leaders and their communities are involved in the design of anti-FC interventions, and begin to integrate awareness about reproductive health, human rights, and FC into local education programs, and allowing for individual decision-making. FC prevention activities can only be successful if they do not negatively affect women's social status in the eyes of religious leaders and the culture and traditions of their communities, therefore all stakeholders must play an active role. 
It is recommended that positive role models be identified in each community, especially respected married women with children who have not been circumcised and/or have chosen not to circumcise their daughters. Other role models could include influential community or religious leaders and highly regarded fathers with status in the community who have chosen not to circumcise their daughters. These role models, acting as local spokespeople for the cause, could help others in changing their attitude and behaviors with regard to FC. This "Positive Deviance Approach" (PROWID program) has been successfully employed in Egypt in 1999 as a tool to empower the community to distinguish between the practice of FC and the values that the practice is intended to symbolize and confer on girls. 


\section{References}

Adrina, et al. 1998. Hak-Hak Reproduksi Perempuan yang Terpasung. Jakarta: Pustaka Harapan, Program Kajian Wanita Universitas Indonesia dan the Ford Foundation.

Ayahbunda, No. 07/2002

Badawi, Jamal. 2002. Gender Equity in Islam. Cited from http://www.soundvision.com/info/gender/femalecircumcision.asp

a Feillard, A. and L. Marcoes. 1998. "Female Circumcision in Indonesia: To "Islamize" in Ceremony or Secrecy." In L'horizon nousantarier, Volume I, Archipel 56: 337-367. Paris: Institut National des langues et Civilisations Orientales.

Imad-ad-Dean Ahmad of Minaret of Freedom Institute, cited in http://www.minaret.org/fgm.htm

IPPF. 2001. "IMAP Statement on Female Genital Mutilation. In IPPF Medical Buletin, 35 (6) December.

Lembaga Studi dan Pengembangan Perempuan dan Anak (LSPPA). 1999. Menjadi Perempuan, Studi Kasus dalam Masyarakat Jawa Islam. Yogyakarta: Pustaka Pelajar Offset.

Materson, J.M and J.H Swanson. 2000. Female Genital Cutting: Breaking the Silence, Enabling Change. Washington: International Center for Research on Women and the Centre for Development and Population Activities.

Pyle, Merrilyn (Edited by Sahar Hegazi.). 2001. Female Genital Cutting in Egypt: Myths and Realities Exposed. Cairo: Population Council-Frontiers in Reprodctive Health.

Rahman, Anita et al. 1999. "Sirkumsisi Perempuan di Indonesia: Pengetahuan dan Sikap Para Tokoh Agama Studi Kasus di Kecamatan Cijeruk-Jawa Barat dan Kecamatan Kemayoran-DKI Jakarta.” Research report presented at National Seminar on "Pengembangan Kajian Perempuan di Indonesia: Fakta, Empiris, Konsep dan Pendekatan, Jakarta, 2-3 August.

Republika, April 21, 2002

Salim Al-Awwa, n.d

Suswati. 1997. Hadis-Hadis Khitan Perempuan (Analisa Sanad dan Matan Hadis). Skripsi: Fakultas Ushuludin, Institut Agama Islam Negeri Sunan Kalijaga, Yogyakarta.

Tatapangarsa. 1980

WHO. 1998. Female Genital Mutilation, An Overview. Geneva:WHO.

WHO. 1996. Female Genital Mutilation: Information Kit. Geneva: Women's Health Family and Reproductive Health-World Health Organization, August.

http://www.keluargamuslim.com

http://www.jannah.org/genderequity/equityappendix.html 